\title{
SEQUENTIAL ANALYSIS OF HUMAN OCCUPATION PATTERNS AND RESOURCE USE IN THE ATACAMA DESERT ${ }^{1}$
}

\author{
ANÁLISIS SECUENCIAL DE LOS PATRONES DE OCUPACIÓN HUMANA Y \\ EXPLOTACIÓN DE RECURSOS EN EL DESIERTO DE ATACAMA
}

\author{
Lautaro Núñez ${ }^{1}$,Martin Grosjean ${ }^{2}$, and Isabel Cartajena ${ }^{3}$
}

\begin{abstract}
This paper presents a chronological sequence of human occupation from the end of the Pleistocene to the present day in the Atacama Desert, one of the most barren territories of the New World. The occupational sequence covers a period of 11,000 years of prehistory, in which distinct patterns of resource use are examined such as hunting, fishing and gathering techniques, animal domestication, agriculture, animal husbandry, mining, commerce and trade. The study also incorporates innovations based on industrial scale mining developments in colonial times, the $19^{\text {th }}$ century industrial period and the present day (extractive mega projects). A variety of cultural, technological and productive developments are discussed in relation to continuity and shifts in human occupations and their impact on the spatial distribution of the population in different locations from the Andes to the Pacific. A marked imbalance can be observed between traditional natural resource production and extractive mining activities that lead to extreme ecological fragility due to the indiscriminate use of water resources. The paper suggests that sustainable development is being jeopardised by the lack of research and alternative models, coupled with a lack of coherence among political, scientific and ethical discourses.
\end{abstract}

Key words: Atacama Desert, prehistoric and historic human occupations, natural resource use, productive innovations.

Se presenta una secuencia cronológica de las ocupaciones humanas del Desierto de Atacama y los distintos patrones de explotación de recursos desde fines del Pleistoceno hasta la actualidad, en uno de los territorios más estériles del Nuevo Mundo. Esta secuencia ocupacional comprende un lapso temporal de 11.000 años, en la cual se examinan las distintas modalidades del manejo de recursos naturales a través de prácticas de caza, pesca, recolección, domesticación de animales, actividades agrarias, pecuarias, mineras, intercambio y comercio. Además, se incorporan las innovaciones basadas en la explotación minera a escala industrial durante el periodo colonial e industrial del siglo XIX hasta la actualidad (megaproyectos extractivos). Se discuten las diversas respuestas culturales, tecnológicas y productivas en términos de continuidad y cambio en las ocupaciones humanas y su impacto en la distribución espacial de la población en los diversos ambientes entre los Andes y el Pacífico. Se observa un acentuado desbalance entre la producción de los recursos naturales tradicionales y las labores minero-extractivas, alcanzando un límite de alta fragilidad ecológica a través de la utilización indiscriminada del recurso hídrico. La carencia de investigaciones y la falta de modelos alternativos ponen en peligro un desarrollo sustentable, en un marco de desencuentro entre discursos políticos, científicos y éticos.

Palabras claves: desierto de Atacama, ocupaciones humanas prehistóricas e históricas, explotación de recursos naturales, innovaciones productivas.

The Atacama Desert is situated between the Loa and Copiapó valleys at the southern end of the great desert that straddles Chile and Peru and is one of the most barren areas of the world (Bowman 1924). This paper focuses on Chile's Region II, in which physiographical, biotical, ecological, cultural and historical features provide evidence of a complex socio-cultural process associated with environmental and adaptive adjustments. Through this, different patterns of occupation can be identified over a large realm of open territory (Núñez 1992a).
Interdisciplinary studies have shown distinct patterns of human occupation and resource use in the region over the past 11,000 years. In this chronological and spatial framework, it is possible to hypothesize why specific cultural, technological, productive and residential responses were implemented in different loci between the Andes and the Pacific. By all accounts, from the end of the Pleistocene to date, the Atacama Desert has presented a dynamic scene, with environmental fluctuations associated with the inhospitable landscape and other natural

1 Instituto de Investigaciones Arqueológicas y Museo, Universidad Católica del Norte, San Pedro de Atacama, Chile. lautaro.nunez@hotmail.com

2 Oeschger Centre for Climate Change Research \&, Institute of Geography, University of Bern, Switzerland. martin.grosjean@oeschger.unibe.ch

3 Departamento de Antropología, Universidad de Chile, Chile. isabel.cartajena@gmail.com 
limitations to human settlement. Still, different spatial and temporal strategies for resource usage can be observed, some more socially complex than others. Studying the innovations introduced via those strategies can expand our knowledge of sociocultural and technological development processes, including adaptive strategies for arid climates such as mobility systems and trade in complementary goods (Castro 1994; Núñez and Dillehay 1979; Núñez et al. 2005; Schiappacasse et al. 1989).

This growing process of social adaptation is overlaid by technological achievements that range from the Palaeolithic-Neolithic innovations to the assimilation of the British industrial revolution and its contemporary repercussions. Nevertheless, these very harsh environments were transformed by societies that managed to tame them and use them for a prolonged prehistoric period (Alonso et al. 2000; Bermúdez 1963; Núñez and Grosjean 2003; Sutulov 1978). During the early historical period, conditions became ripe for the introduction of several technological changes of a commercial nature that led to the dissipation of indigenous communities of the region. Thus, from the early $19^{\text {th }}$ century onwards, modes of territorial occupation and Spanish technology became obsolete, paving the way for one of the first "capitalist colonizations" under the British commercial expansion to exploit foreign desert resources. The paragraphs below trace different patterns over time to examine continuity and change in human occupations and uses of the Atacama Desert.

\section{Fell-Tuina Early Occupational Pattern $\left(10,820-8,500 \mathrm{BP}\right.$, ages $\mathrm{BP}$ given in ${ }^{14} \mathrm{C}$ yr BP)}

It is generally accepted that the initial occupation of the Atacama Desert occurred during the late Pleistocene era, at the end of the Ice Age, associated with favourable paleoenvironments with a more humid climate than at present (Grosjean and Núñez 1994; Núñez et al. 2002). These early inhabitants were groups that intermittently occupied open air camps on the edges of the paleo wetlands located NE of the Punta Negra Salt Flat basin and other paleo wetland and lake sites, where camelids and associated plant resources were concentrated. These hunter-gatherer groups used projectiles, triangular and Fell points, similar to those commonly recorded at sites in Central and Southern Chile, for hunting Pleistocene megafauna and modern herbivores
(Grosjean, Messerli, Amman et al. 1997; Núñez et al. 2005).

The artefacts found in the Salar Punta Negra area include large scale production of stone tools suitable for hunting, slaughter and gathering, notably racloirs, knives and unifacial scrapers from large basalt flakes obtained from nearby outcrops. These sites comprise a unique collection of stone artefacts that are not found in similar locations elsewhere in the Atacama Desert, but rather around the Pleistocene lakes and steppes of the central and southern regions of the country (Núñez, Casamiquela, Schiappacasse et al. 1994; Núñez et al. 2005) (Figure 1).

The Tuina occupations, contemporary with those of the Fell, include several Andean hunter-gatherer settlements located in caves along intermediate ravines and in open air camps on the beaches and meadows of paleolake environments. All of the sites are strongly associated with circum-puna highland resources. They practiced nomadism or seasonal migration (transhumancy) to take advantage of the resources of the highland paleolakes and those of the ravines, which generally contained watercourses and/or freshwater springs. This constitutes the first stable occupation associated with the groups' characteristic triangular bifacial points (Núñez 1992b; Núñez et al. 2002). There is evidence that these groups hunted camelids and, to a lesser extent, deer and a Pleistocene equidae in precordillera environments (Tuina) and gathered plants for grinding in intermediate ravines and meadows on the eastern boundary of the present-day Atacama Salt Flat (Núñez et al. 2005).

Given their wide distribution, these groups are thought to have lived in the circum-Puna highlands, above 2,000 masl, moving from one resource-rich area to another. Their movements are closely associated with high Andean hunting and gathering resources in environments such as meadows, groves and foothill scrublands on the eastern and western slopes of the Alta Puna (Aschero 2000). With this occupational pattern, exploitation of lake resources and high Andean foraging commenced, in parallel with the use of resources from the Loa River and the streams of the Atacama basin, including those in the mountains, spring-fed ravines, meadows and small lagoons on the eastern edge of the present-day Atacama Salt Flat (Figure 1).

This period saw the emergence of human occupations characterized by hunting, fishing and gathering along the resource-rich coastline near the 


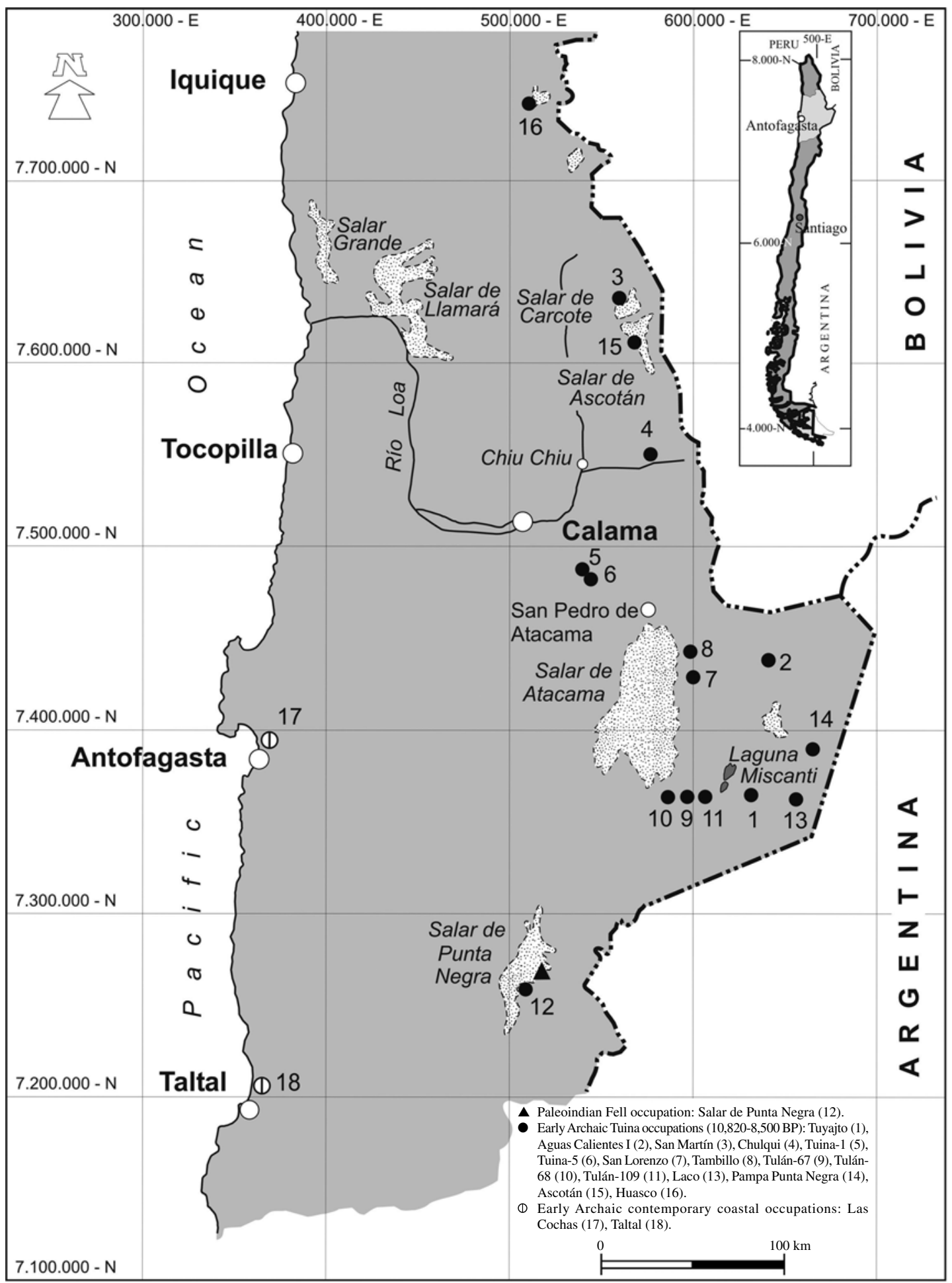

Figure 1. Early Holocene. Early Tuina and Fell occupational pattern (10,820-8,500 BP). Holoceno Temprano. Patrón ocupacional temprano Tuina y Fell (10.820-8.500 a.p.). 
mouth of the Loa River and near springs that were fed by water collected from sea fog or from tectonic fault lines in the coastal mountain range (Núñez and Varela 1967). Still, it is remarkable the lack of early Pleistocene/Holocene archaeological sites found along the current coastline and the adjacent lowlying terraces (Figure 1) (Llagostera et al. 1997). This deficiency is explained by the rising sea level after the last global glacial maximum that lasted through the Early Holocene and stabilized around 6,000 years B.P. This implies that early sites situated on paleobeaches are currently submerged, making their visual discovery impossible at present.

In general, very little is known about the local paleoenvironments of sites identified in high terraces or in the Coastal Mountain Range. However, the authors propose that certain sites near paleosprings had little potable water, while those near the mouth of the Loa River had abundant potable water, based on the water flowing down this watercourse from the upper mountain reaches (Grosjean et al. 2007). Because of this, the few coastal sites contemporary with the occupational pattern under discussion have been found no more than $15 \mathrm{~km}$ inland, near springs and wetlands, and away from the area of marine transgression. The coastal groups required plant resources and rocks suitable for toolmaking at these sites. These camps contain subsistence resources brought mainly from the coast. Also, in some cases, early burial sites were found (Muñoz and Chacama 1993; Núñez 1983a). One such case has been identified on the Atacama Desert coast: The Las Conchas settlement, situated at the base of the coastal mountains in an area with potable water, located above the marine abrasion platform and dated to around 9,700 BP. The site contains evidence of wet events possibly linked to the "El Niño" current such as consumption of warm water fish (Llagostera 1979). The Huentelauquén coastal pattern identified at Las Conchas, contemporary with the Tuina pattern, is very likely present in other settlements too: these are characterised by dense shellfish and fish remains situated high up on the coast in locations that are not affected by the recurrent marine transgressions which shaped the coast from the Atacama Desert to Central Chile. These sites are typified by the presence of polygonal lithic fragments and steamed points (Jackson and Mendez 2005).

In fact, recent findings on the Taltal coast show that the so-called Huentelauquén occupations, dated to the same time range as the Tuina and Fell patterns, confirm the existence of different occupational traditions during the initial settlement of the circum-puna desert region (Castelleti 2005; Núñez et al. 2005). It has been suggested that early sites along the Peruvian and Chilean desert coast were submerged after the sea level rose (Grosjean et al. 2007). Thus, the distribution of these first occupations should be considered to have been more extensive (Figure 1). Given the available evidence from the earliest occupations of the circum-Puna and adjacent coastlines, it is suggested that two parallel types for resource extraction had developed, one on the coastline and one in the Andes Mountains. Although the dates of the Tuina sites are slightly older, the abundancy of coastal resources suggests that the first explorers arrived at the end of the Pleistocene coastline and occupied the coast not only in southern Peru (e.g. Sandweiss et al. 1998), but also near Taltal and the Atacama Desert (Castelleti 2005). The area between the coast and the mountains remained largely unoccupied and does not show any signs of human occupation until the most recent settlements associated with the nitrate (Salitre) mining industry in the $19^{\text {th }}$ century (Bermúdez 1963, 1966).

\section{Puripica-Tulán Occupational Pattern (5,100-3,800 BP)}

During the arid Middle Holocene, groups of inland hunter-gatherer lived in camps in the pre-Puna ravines, where resources were concentrated in the floors of valleys (ecological refuges) such as Puripica and Tulán. The nomadic movements of these groups distributed them around the lakeside beaches of the highland basins, including intermediate ravines such as Tulán, Puripica and Chulqui, and throughout the Loa and Atacama basins (Figure 2). The arid conditions that prevailed during the Middle Holocene seem to have prompted the groups' movement to other productive zones, specifically microhabitats, making the frequency of dated sites much lower than in the earlier periods. Habitats were predominantly found in the eco-refuges (Grosjean et al. 2005b, Grosjean, Núñez, Cartajena et al. 1997; Núñez et al. 2005, 1999). Without doubt, the isolated concentration of flora and fauna, especially around year-round springs and meadows, enabled the establishment of archaic settlements in the pre-Puna sectors of the Loa and Atacama basins (including the adjacent High Puna). These groups hunted, domesticated 


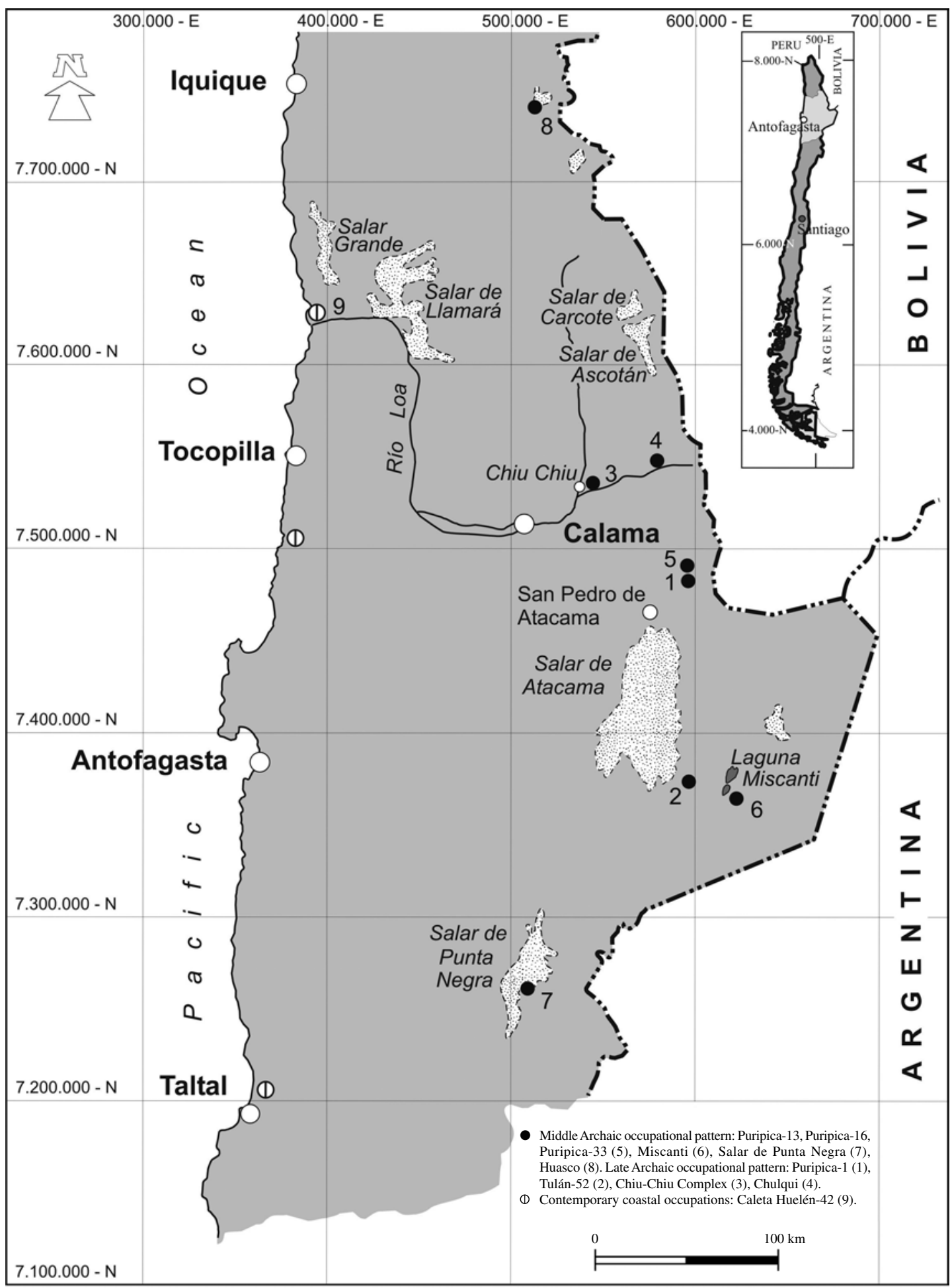

Figure 2. Middle Holocene. Late Archaic Puripica/Tulán occupational pattern (5,100-3,800 BP).

Holoceno Medio. Patrón ocupacional Arcaico Tardío Puripica/Tulán (5.100-3.800 a.p.). 
camelids, collected plants and maintained contact with the Pacific coast.

Undoubtedly, additional early sites of this nature in the above-mentioned ravines were eroded between 8,500 and 6,500 BP and destroyed. Others were replaced by large, quasi-sedentary settlements with collections of sub-circular dwellings dated at approximately 5,000-4,000 BP in the Puripica sector. These settlements were contemporaneous with the Tulán ravine and Chiu Chiu (Loa valley) camps, and are associated with the first evidence of camelid domestication in the context of complex hunting societies (Cartajena et al. 2005, 2007; Mengoni and Yacobaccio 2006). These mid- to late Archaic events are associated with the use of restricted spaces at moderate altitudes (3,000-2,000 masl) in narrow ravines, suitable for subsistence strategies based on hunting and camelid rearing more than on horticultural activities (Núñez et al. 1999).

These camps were small and in enclosed spaces that accommodated dense populations that used seasonal subsistence resources (animals and plants). Many of these sites were near source areas of raw material for lithic artefacts e.g., high Andean obsidian. However, the movement of groups from these sites up into the highlands and down to the adjacent arid coast is very likely since the arid climate did not affect marine resources on the coast. It has, therefore, been suggested that during the Middle Holocene, the coastal population increased considerably as people moved from inland areas to coastal sites with freshwater springs and protected beaches. Indeed, there are many Archaic camps that exhibit circular, semi-agglomerated residential structures and widespread deposits of fish and shellfish middens as e.g., in Taltal, Cobija, Tocopilla, and at the mouth of the Loa river (Grosjean et al. 2007). These are thought to reflect a much wider distribution than that shown in Figure 2. The most representative case is the settlement complex Caleta Huelén-42 $\left({ }^{14} \mathrm{C}\right.$ dated to $4780-3780 \mathrm{BP}$, Ggak 3545 and 3546; coal and wood, respectively, Núñez 1983b: Table 1), which shows unequivocal evidence of sedentarism associated with a small village of fisher-gatherers. The features of this settlement suggest that it could be a re-adaptive response to the Puripica-Tulán Andean pattern or, alternatively, the result of intense interaction between the mouth of the Loa River and Taltal (Circumpunean coastline), that brought the inland (Andean) Archaic architecture and other cultural features to the coast (e.g. Caleta Huelén
42). Among these are the style of petroglyphs that is recognisable from the Puna foothills (known as Kalina-Puripica style), rocks with engraved lines, and the remains of obsidian and feathers from the Andean parrot. Such findings are considered unequivocal evidence of long-distance contact between the midlands and the highlands and the coast during the Middle Holocene (Núñez et al. 1974).

While it is true that there are many coastal occupations within the chronological range of the Puripica- Tulán pattern, this distribution lacks sufficient dating. On the other hand, the tendency towards fewer identified inland sites of the Puripica- Tulán pattern seems to be due to regional aridity. Thus, it is possible to affirm that the desert coastline was inhabited temporarily or permanently by groups of inland hunter-gatherers who seem to have lived from hunting and camelid raising and who increased their contact with the coast during arid climatic events (Grosjean et al. 2007; Núñez et al. 1999). It is generally accepted that a combination of favourable environmental and cultural conditions led to increasing social complexity and the specialized exploitation of sites where natural resources were abundant (eco-refuges). These were concentrated habitats at specific altitudes that were associated with complementary resources -groves of Prosopis, raw stone material, fodder from mountain meadows and shrublands- in narrow ravines in which wild and domesticated camelids were the main resource.

\section{Tilocalar Occupational Pattern (3,500-2,500 BP)}

Several paleoenvironmental studies have suggested that during the Late Holocene, from the start of the Tilocalar occupational pattern onwards, the arid climate changed to more humid conditions, leading to improvement of the Andean grasslands and re-establishing of lakes that remain to this day (Grosjean et al. 1996; Núñez 1999b). The achievements of the hunters from the earlier occupational pattern persisted in the same habitat as before through the emergence of settlements that were more densely populated and complex. These had village-type architecture and lived from camelid hunting and herding, in an increasing process of neolithization (Early Formative Period). Also, horticultural activities (growing of maize, quinoa, chilies and cucurbits), are the first evidence of stable agricultural-pastoralist settlements, located in narrow 
ravines suitable for hunting and pastoralism such as Puripica and Tulán (3,000 masl). Other pastoralist settlements were spread in the wetlands and river courses in Chiu Chiu and other eco-shelters of the Salado River (Benavente 1984; Núñez, Cartajena, Carrasco et al. 2006; Sinclaire 2004).

The Tilocalar occupations reflect the transition from the former hunting-gathering and animal raising pattern to food production based on agriculture and livestock raising, along with the continued use of camelid hunting in the same eco-shelters and in the intermediate ravines of the warm foothill oases (Figure 3). Some very stable settlements can be observed in these small villages in the Tulán ravine: agglomerated, sub-circular residential structures, a semi-subterranean central shrine used for offerings and the burial of newborn infants, with built-in wall niches and petroglyphs depicting camelids. All of these village compounds were littered with mounds of domestic and ceremonial waste, indicating that the intermediate ravines were more suitable areas for the development of this occupational pattern than the foothill oases. This pattern led to major technological innovations in animal husbandry, horticulture, mining, metallurgy and ceramics, as well as large scale rock art and stone sculpture, recognized collectively as an unprecedented and highly complex transformation. Judging from their ritual and domestic architectural program, which includes large waste heaps and the first cemeteries found in this area (Núñez et al. 2006), these villages are the first symbolic and domestic points of reference for completely operational sedentary settlements with a stable organisation.

The Tilocalar pattern ushered in innovative domestic practices (llama raising and crops growing), which gradually spread out until farming-pastoralism became the prevalent way of life in the Loa and Atacama basins, including the Puna hinterland the inhabitants interacted with. This socio-economic shift occurred in the same ravine loci in the Atacama and Middle Loa domain, where the archaic huntergatherer society had built their semi-stable habitats. This change hardly involved the warm oases in the Atacama basin foothills, but was concentrated in the intermediate ravines, shrublands and high Andean lake basins (e.g., Puripica and Tulán).

There are also signs of the Tilocalar pattern in the Loa and Atacama basins, judging by the distribution of their architectural, domestic and ritual formats, the Taira-Tulán style petroglyphs, the extensive use of monochrome ceramics, and the emphasis on camelid hunting and raising. Further evidence includes mining and metallurgy, textile making, the perforating industry, caravan expeditions to the coast and the connection with goods from the eastern Yungas region, the mountain rainforests on the eastern slope of the Andes in NW Argentina and S Bolivia (Núñez et al. 2006). Although no other loci of village compounds of the Tilocalar pattern are known, apart from Tulán, the pasturing and growing areas of the Early Formative period are thought to have been only sparsely populated, meaning that the territory offered a much greater carrying capacity for future expansion (Agüero 2005).

Along the arid circum-Puna coast, which is characterized by the absence of river courses, cemeteries and/or cultural evidence comparable to the Tilocalar pattern had been established near the sea in areas with freshwater springs and at the mouth of the Loa River (Pimentel et al. 2006). It is not yet clear if the burial mounds between Cobija and the Loa River and other indications of funerary rites from Taltal correspond to re-adaptive adjustments to the Pacific coast by groups that usually inhabited the lowland westfacing valleys between Arica and Tiliviche/Camerones. In one way or another, the remarkable agricultural transformation that occurred on the edge of the pre-Puna in the basins mentioned above would have had repercussions on the coast, even though the nature of such impacts is not known, except for obvious trading operations (Capdeville 1921; Moragas 1982; Núñez 1971, 1984).

\section{Tulor Occupational Pattern $(2,500-1,550 \mathrm{BP})$}

The large number of farming and livestock raising settlements coinciding with this occupational pattern, many of them with radiocarbon dates, points to a major expansion of sedentary villages during the middle and late Formative Period. The villages in the Loa area and in the ravines and oases of the Atacama foothills became self-sufficient food producers once the modern climate was established (Figure 4). This could be explained by a shift from gardening practices towards more extensive farming in the area of warm foothill oases, where the low altitude allowed growing of tropical and semitropical crops (e.g., corn, chilies, beans, and cucurbits among others). 


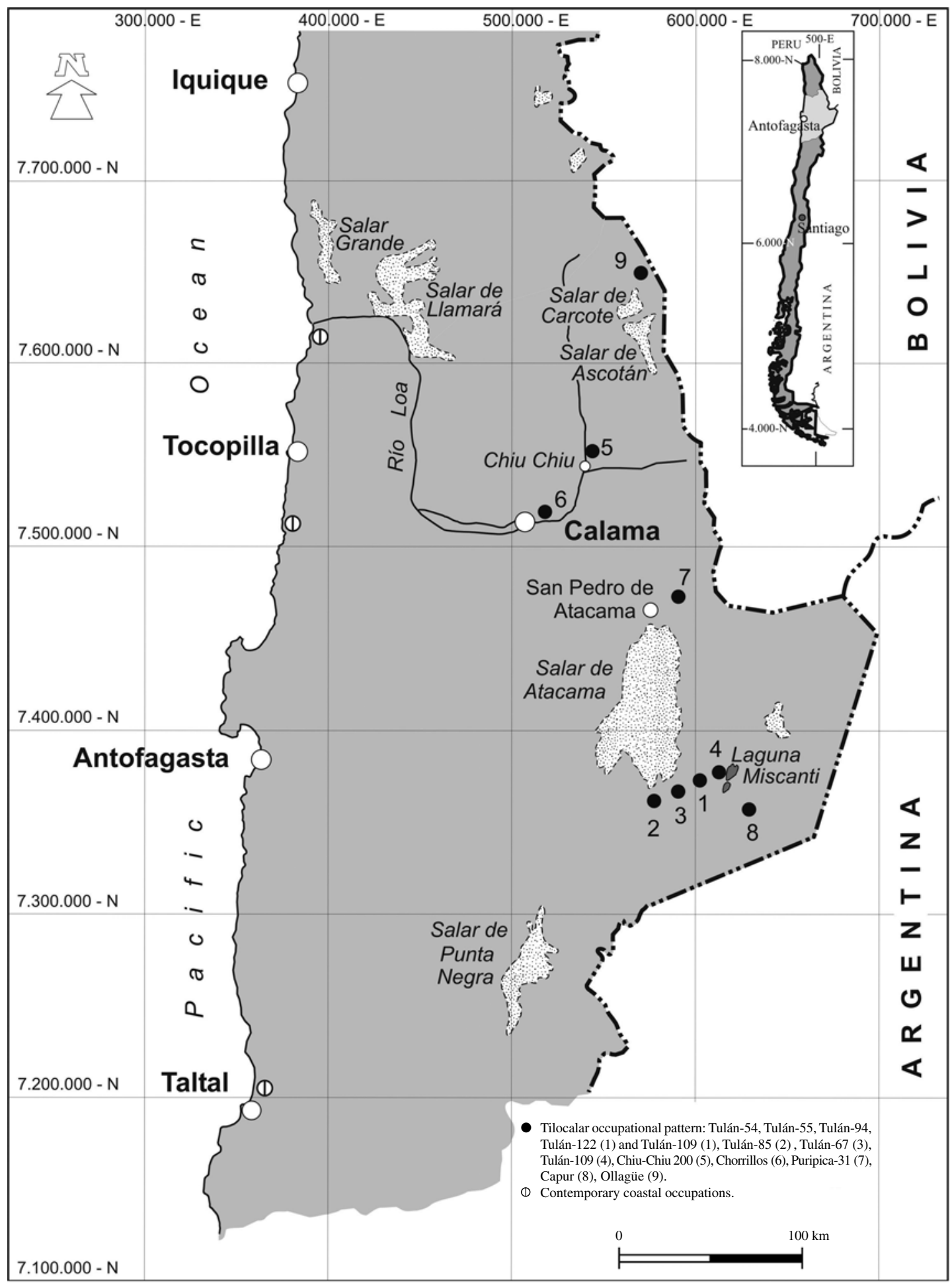

Figure 3. Late Holocene. Early Formative Tilocalar occupational pattern (3,500-2,500 BP). Holoceno Tardío. Patrón ocupacional Formativo Temprano Tilocalar (3.500-2.500 a.p.). 


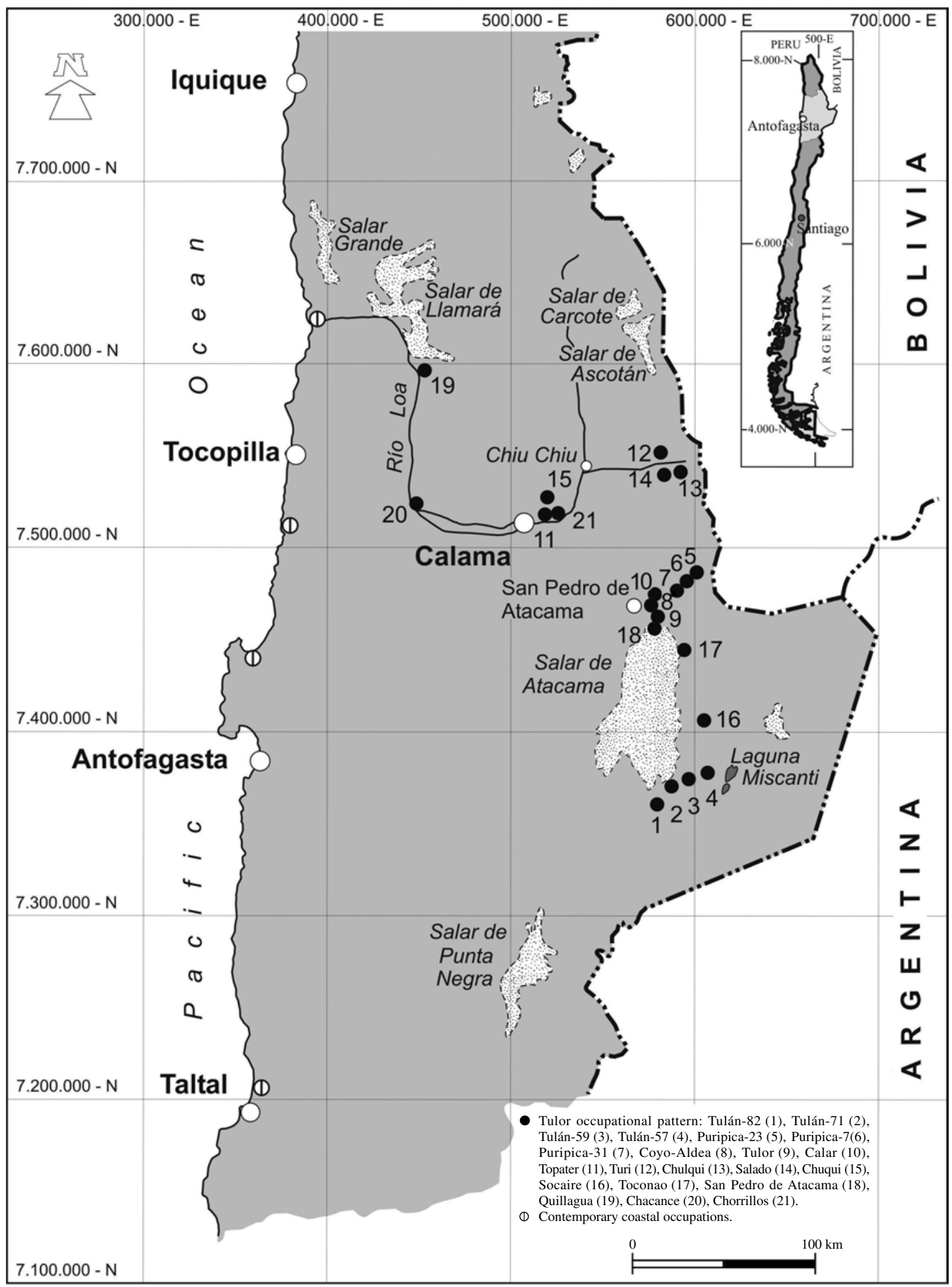

Figure 4. Late Holocene. Tulor occupational pattern (2,400-1,550 BP).

Holoceno Tardío. Patrón ocupacional Tulor (2.400-1.550 a.p.). 
The location of these cropping fields, initially irrigated with flooding techniques, at river mouths, (e.g., Tulor), among dense groves fed by groundwater, allowed for the growing of edible fruit such as the algarrobo and the chañar. Human occupation was concentrated in the most humid sectors, where the trees protected crops from intense erosive activity and provided shade to prevent intense local evaporation.

This agroforestry combination, so common in the foothill oases of the Atacama basin and at Chiu Chiu in the Loa, paved the way for the development of a social and political centre where the town of San Pedro de Atacama stands today. This led to an expansion of the Tulor, Calar and Coyo villages, with their characteristic dense sub-circular residential groupings. The activities from these centres reached to the pastures and shrub lands of the high ravines (3,000 masl) and even to the high Andean grasslands and lake basins.

The presence of cultural components belonging to this pattern, such as the black polished pottery found in numerous cemeteries along the circum-Puna coastline, some of it dated within this timeframe, shows that these settlements were part of a socio-political centre (Atacama) that organised macro-spatial relationships with other societies and resources with groups to both sides towards the Pacific coast and also to the Argentine Puna. These relations included caravan contact with mining sites located on the borders of the circum-Puna sub-area (Llagostera et al. 1984; Orellana 1990; Olivera 1998; C. Westfall, personal communication, 2007) and with countless remote villages situated on the eastern watershed of the Argentine Puna (Tarragó 1989). Without a doubt, during this occupational pattern the increase in agricultural activity, livestock raising, mining and caravan transport led to a great expansion to virtually all areas with sufficient water resources (Núñez 2005). It is generally accepted that, during the timeframe of this pattern, the lake waters reached their highest levels recorded in the past 8000 years, that is to say, humidity was favourable, which is backed up by records from the Miscanti paleolake basin (Grosjean et al. 2001). Given the high lake water levels and the later dry period, it could be suggested that towards the end of the Tulor pattern a dry climate seems to have prevailed that affected both surface water and groundwater resources (Núñez et al. 2006).
The considerable record of craftwork derived from Tiwanaku iconography (AD 600-1,000), would suggest that during this time caravan trade was intense, mainly as a result of early and successful use of local resources (Berenguer 1998). However, it has been suggested that in the circum-Titicaca and Southern Altiplano area a severe drought took place around 1,000-1,400 BP, even causing the downfall of Tiwanaku (Binford et al. 1997). Although it is not known how far west the deterioration of biotic resources extended, it is possible that productive areas on the western side of the Andes received migrants from the Altiplano, at the same time as caravan trade in prestige goods and food intensified (Berenguer 2004).

\section{Solor Occupational Pattern (1,550 BP-AD 1,450)}

This occupational pattern shows the highest frequency of farming and livestock raising settlements identified in the Loa and Atacama basins. These were territorially organized and included at least three socio-political centres: one in the Atacama valley, one in the middle and one in the upper Loa valley. These groups made use of all land that could be irrigated, and even grew crops on man-made terraces in middle and high ravines with a year-round water supply (Schiappacasse et al. 1989). Indeed, it could be said that all contemporary indigenous villages of the region, which correspond to the Atacameño people, have remained beside such installations, as long as water and soils were available (Figure 5).

Agriculture had now developed across the region, enclosing both basins within one ethnic community different from that of the Altiplano and acknowledged by the first Europeans as Atacameño natives. Dated settlements are distributed not only along the largest water courses, but also appear as isolated enclaves during the peak of agrarian expansion. These are well represented in the ayllos of the Atacama valley, where distinct villages have been identified and marked by their respective cemeteries, indicating that a truly sedentary way of life is linked to regular funeral rites associated with a group's ancestors.

The end of the arid interval in the neighbouring Altiplano area (AD 1,400) may have had repercussions in this area, causing certain Altiplano groups to occupy marginal zones through alliances made 


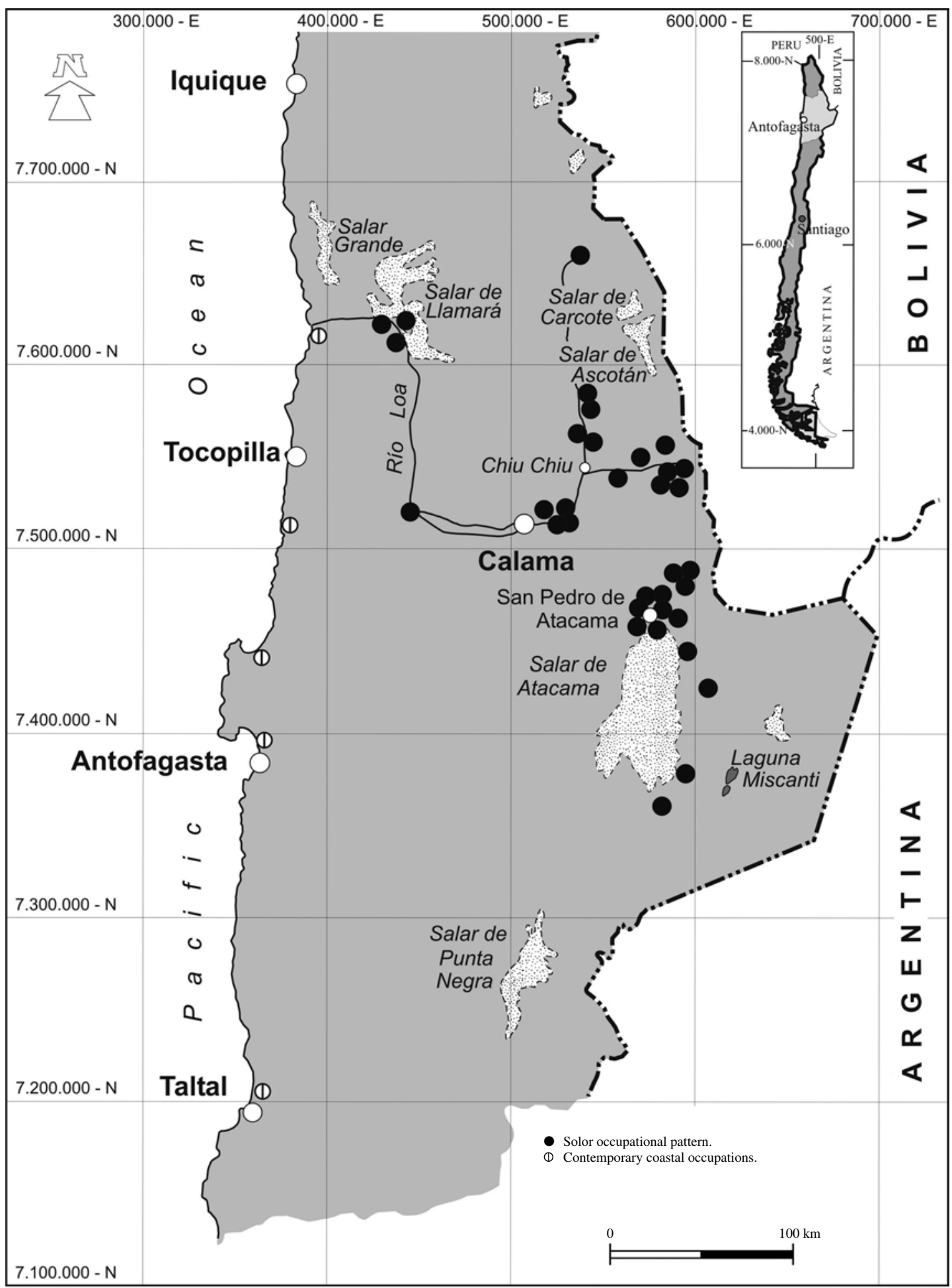

Figure 5. Late Holocene. Solor occupational pattern (1,550 BP-AD 1,450).

Holoceno Tardío. Patrón ocupacional Solor (1.550 a.p.-1.450 d.C.). 
with local elites, thereby increasing long distance caravan trade (Berenguer 2004; Núñez and Dillehay 1979). If true, a strong push to improved water use is expected involving hydraulic engineering works such as irrigation canals and dams. Terraces would also have been built and water brought down from high to lower altitudes where larger areas of open land were available for farming (Castro et al. 2004; P. Núñez 1992). This highly complex and productive scenario fostered trade in domestic and ritual goods throughout most of the south central Andes, first by means of long distance caravan trade with the Tiwanaku Altiplano state and with socio-political centres of the Aguada culture in the southern valleys, and later with communities closer to the southern Altiplano and northeast Argentina.

In the present sector of ayllo Beter, residential areas were excavated in Beter-3 village under this immediately pre-Inca pattern, where a residential peak was located, based on cultivation of maize using canal irrigation and supplemented by fruit gathering from Prosopis trees. The pollen spectrum analysis showed signs of Chenopodiaceae (aff. Atriplex), Poaceae (aff. Distichlis) and traces of Mimoseae (aff. Prosopis), Asteraceae and Poaceae, which are associated with arid climates similar to those of the present day; other species are indicative of more humid conditions (Poaceae and Asteraceae) (Marquet et al. 1998).

Along the Pacific coastline, outside the range of climate changes in the high Andes, local occupations enjoyed subordinate relations with the socio-political agrarian centres in the Loa and Atacama basins. The population had grown to the point where permanent settlements had been established in all major caletas (sheltered bays). From here, the inhabitants moved around to fish, gather and carry out mining in resource-rich areas, establishing secondary camps, collecting surplus and storing subsistence and prestige goods that were traded to the caravans crossing the desert from the inland oases. Some noteworthy concentrations of dated permanent sites along the desert coast suggest that major present-day ports built during colonial times and the early days of Chilean independence were located precisely in areas where the main preHispanic coastal occupations have been identified. These include Iquique-Bajo Molle, Boca del Loa, Tocopilla-Cobija, Mejillones-Antofagasta (Cerro Moreno Penninsula habitat), and Paposo-Taltal. To this day, the coastal resources and the inland agricultural and livestock resources are two parallel and complementary productive bands, separated by the extremely arid intermediate depression, which can only be crossed by a complex network of trade routes.

\section{Catarpe Occupational Pattern (AD 1,450-1,520)}

The scenario described above was affected by the Inca expansion, which imposed imperial control over its annexed territories and established a new order. Alliances with local elites gave the Inca quick control over a subordinated workforce through a labour tribute system. The aim was to produce a surplus of agricultural, animal and craft goods, as well as mining and metallurgical prestige goods along with the means to transport them (Núñez et al. 2005; Schiappacasse et al. 1989).

To this effect, the Inca controlled the population directly by building structures and facilities to service and administer the territory. These were established beside existing settlements where the new rulers co-existed with the local authorities, or in separate, exclusive administrative centres. They used to manage road networks and local nearby productive areas (Castro et al. 2004; Sanhueza 2005) (Figure 6).

The Inca Empire's political and administrative control over the same productive areas used by the local people extended to the complex trans-desert road system, which had already been used to transport domestic and prestige goods well before the Inca arrived. In effect, the Inca built a chain of tambos (waystations) to support the transport of people and goods along the now-named Inca Road, which extended into the annexed regions that supplied goods through local elites. Although the Inca administration increased surplus food production to supply their armies and made use of the mitas (tribute labourers) working the land for the benefit of the Inca line and the sun god, the Empire's greatest impact was caused by the significant expansion of local mining activity outside of socio-political centres, which were located in more marginal agrarian areas. This territorial expansion into mining areas reached preexisting copper mines in the places now known as Chuquicamata, Abra, Tomic, Sierra Gorda/Spence, costa del Loa, Miño, El Salvador and Peine. Other major mining centres were also affected, including, of course, San Bartolo, Caspana, Peine, Chulacao, 


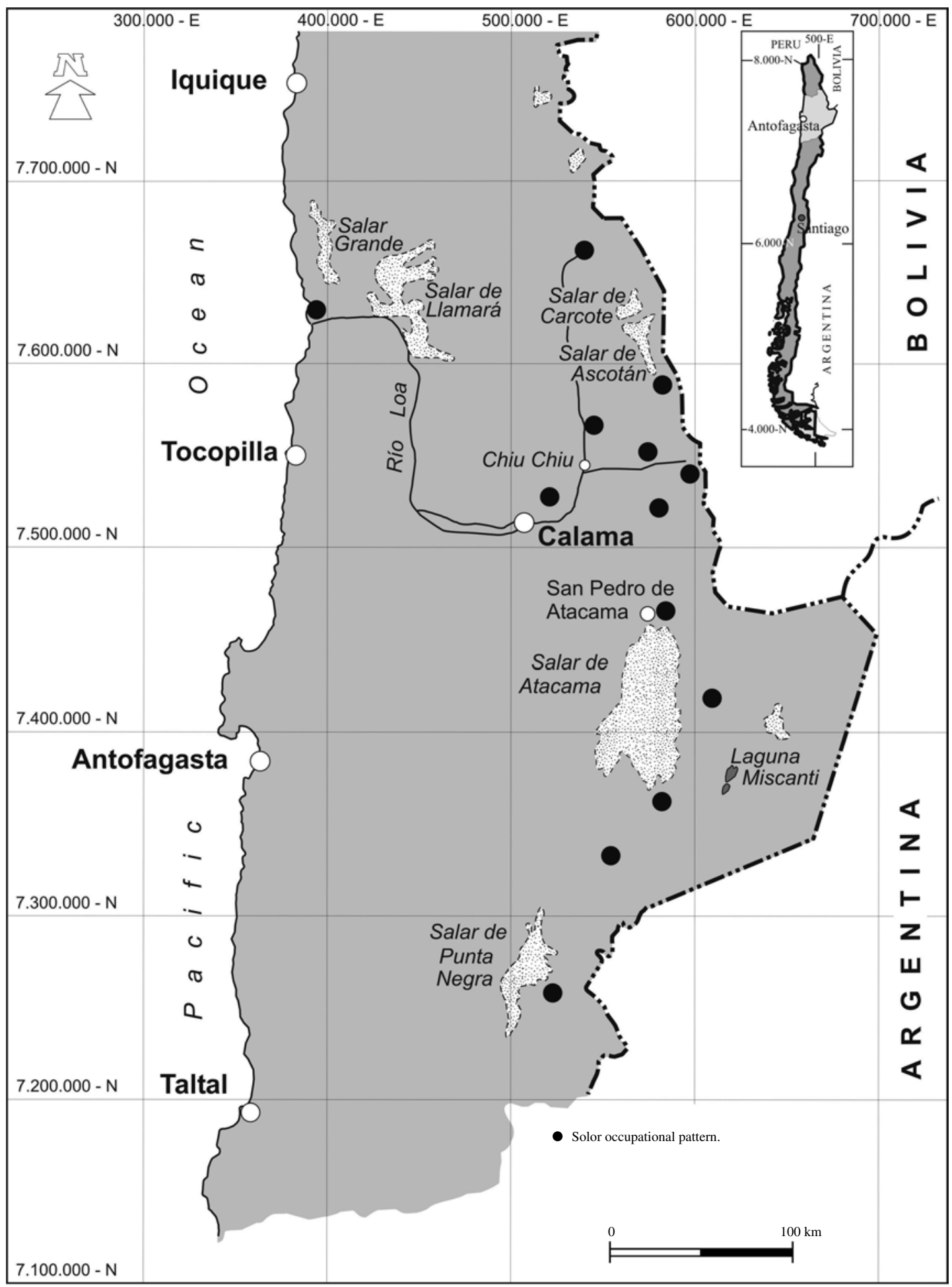

Figure 6. Late Holocene. Catarpe, Inka occupational pattern (AD 1,450-1,520). Holoceno Tardío. Patrón ocupacional Inka Catarpe (1.450-1.520 d.C.). 
which were located next to water courses. These facilities were operated by groups of Atacamans (Atacameños) who, long before the Inca arrived, had become experts in accessing both nearby and remote resources using the seasonal caravan routes (Núñez 1999a; Salazar et al. 2001). For the same reasons, local agricultural surpluses were increased in order to supply the Inca troop movements and to feed local workers who worked now to the benefit of the Inca state.

Clearly, the most noteworthy innovation was the implementation of the Inca mining and metallurgy policy, which focused on taking advantage of the expertise of generations of local inhabitants who had worked the gold and copper deposits since $2,500 \mathrm{BP}$. This group had their own rank in the local society based on their expertise in this activity. It seems apparent, then, that the mining developments of the subsequent historical periods originated in the exploration and exploitation of mineral resources in the Atacama Desert carried out by the indigenous societies of pre-Inca and Inca times.

\section{Beter Occupational Pattern (AD 1,520-1,800)}

During the Spanish invasion and colonisation, the Atacama Desert was initially seen as a territory whose crossing was purely for the purpose of "matalotaje", i.e. meeting the basic needs of the army to enable evangelisation and military conquest (Núñez 1992b; Téllez 1989). Later, colonization of the region led to several profound changes that had a direct impact on native societies and environments. The first European authorities exercised their power from residences and gardens built alongside the churches. Later, in the $17^{\text {th }}$ century, the Toledo policy segregated the growing European community from the indigenous population through the latter's "reduction and pacification" into so-called "pueblos de indios" (native towns). Although no attempt was made to change the indigenous way of life, their ayllos were eradicated and/or rural settlements dispersed; they were forced to pay tribute in goods and had to submit to the rule of 'Indian authorities' appointed by the Spanish bureaucracy. All of this significantly altered traditional indigenous attitudes to local resources and ancestors, and led to confusing, anti-indigenous urban developments.

This new order culminated at the end of the $18^{\text {th }}$ century with the application of an urbanisation program in San Pedro de Atacama and in other foothill oases (Hidalgo 1981) (Figure 7).

Obviously, the best lands of the Atacama region were appropriated, first by the Spanish crown and then by the colonists, who dramatically changed the way the land was used to suit their own cultural and mercantile interests, which had little in common with indigenous traditions. The colonists cultivated crops of maize, broad beans and vegetables and planted vineyards and fruit orchards. Mostly, however, they grew alfalfa for cattle, goat and horse fodder. The horses were used for local transport of goods and for cattle drives in the livestock trade with northeast Argentina, which expanded in the late $18^{\text {th }}$ and early $19^{\text {th }}$ century. This led to the emergence of an elite class, mercantile rather than agrarian, which handled the traffic of European goods and dried fish from the Cobija-Loa coast to Potosí, while mule trains transported foreign goods for colonial families who controlled the wealth that flowed from the silver mines of the central and southern Altiplano (Martínez et al. 1990).

Two interconnected aspects of the colonial mercantile period are worth noting. The first one was the trade monopoly based on the pre-Hispanic production of dried fish. The other was the transdesert movement of this commodity, first by llama caravan and then by mule train, from ports leased by Spanish contractors to expand surplus goods supplied to the Altiplano mining markets (Martínez 1985, Martínez et al. 1990). The pre-Hispanic trans-desert routes that connected the Atacaman farming centres with the coast coordinated the movement of goods according to their monetary value, a concept that was unknown in local exchange practices and, therefore, served to further marginalize indigenous people and increase their dependency. At the same time, the indigenous caravan exchange continued on the periphery of these new European institutions, in the circum-Puna sub-areas and the southern Altiplano. This trade network was facilitated by inter-ethnic alliances and marriage, preserving ethnic traditions within a framework of co-existence of two opposite forms of macro-regional interaction. This would lead to the enrichment of local families of Spanish origin. And thus, in the $18^{\text {th }}$ century the new Hispanic elite sought large scale commercial returns by means of the road link from Cobija to Potosí. By acting as mandatory intermediaries based in San Pedro 


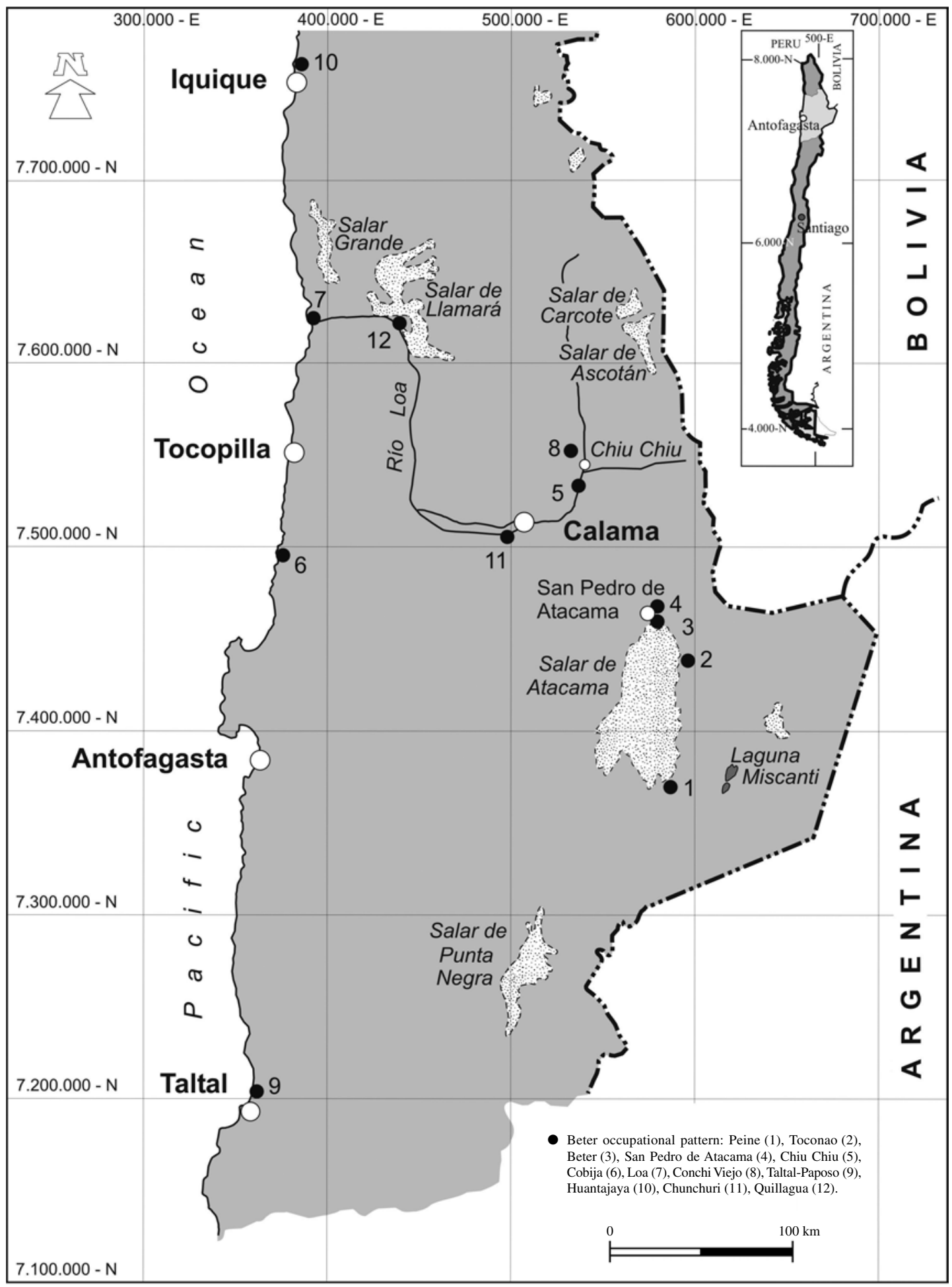

Figure 7. Late Holocene. Beter occupational pattern (AD 1,520-1,800). Holoceno Tardío. Patrón ocupacional Beter (1.520-1.800 d.C.). 
de Atacama and Chiu-Chiu-Calama, they were able to control all resources that were transported across the desert (Sanhueza 1991).

In this "modern" scenario, both imported and local Andean resources were transported by indigenous mule drivers who had been uprooted from their lands by these new commercial structures, which left no room for the Atacaman communities. The criollo $^{2}$ (Spanish-descendant) authorities had introduced imported livestock (cattle, sheep, goats and horses) in the local communities and planted crops of European origin, leading to significant reductions in indigenous crops such as maize in favour of wheat. This practise gradually became common among Atacaman communities, as did several other major changes in the local culture and way of life (Núñez 1992b).

Excavations in residential areas have identified the introduction of European products during the Beter colonial occupation. For instance, wheat cultivation increased dramatically with the construction of a complex underground water irrigation system in the Larache ayllo, quintupling the acreage of melgas (plots of land dividing a field to facilitate even ploughing and sowing). Moreover, wheat refuse has been found in adobe constructions of the time, and from the $17^{\text {th }}$ century onward there was a marked reduction in indigenous crops such as corn. In the Beter colonial settlement, there has been found evidence of craftworks and metal smelting, pointing to the intensive use of firewood and an increasing shift of the workforce towards non-agricultural activities. In addition, the presence of bird, cattle, horse and sheep remains associated with fruit orchards seems to indicate a noticeable change in land use patterns and in the raising, feeding and care of livestock that was more suited to European herbivores (Marquet et al. 1998).

The effect of European agriculture, livestock and horticulture is seen in the lowland oases near their settlements, precisely where the indigenous communities kept their fields. There, foreign technological applications such as watermills, wine growing, fruit drying and high yield alfalfa cultivation spread quickly, standardizing indigenous and criollo production. However, unlike native agriculture, which focused on producing food, the new practices concentrated on intensive alfalfa farming and cattle handling at the oases as cattle drives in the Atacama increased. Cattle driving, connected with the criollo trade in cattle from northeast Argentina, led to cattle and goats pressuring the already fragile forage resources of the oases and intermediate ravines. Thus, land that had formerly been used for indigenous food production was made unavailable, while the indigenous practice of raising llamas and alpacas gradually disappeared.

A new ownership model for productive land, based on criollo farms or haciendas and far removed from the principle of indigenous community land ownership, led to a gradual breakdown in land holding. At the same time, settlements were forced to change, the indigenous Kunza language was eradicated in favour of Spanish, and tributes became obligatory, causing the widespread abandonment of indigenous resources and settlements. The displaced indigenous population migrated permanently or temporarily to the valleys of northeast Argentina, or opted to work on criollo farms, to drive mules or to work in the mines close to nearby valleys (e.g., San José del Abra/Conchi).

The El Abra copper deposit in Conchi Viejo in the deserted Chuquicamata area points to another important colonial innovation, as the colonists managed to greatly surpass the scale of indigenous mining, bringing the activity to pre-industrial levels. At this time, settlements began to sprout up in unpopulated areas such as Conchi, giving way to a way of life not witnessed before, in which communities were established next to remote mining operations. Such installations would multiply considerably in the upcoming $19^{\text {th }}$ century (Figure 8 ).

Because of the emphasis on smelting in $17^{\text {th }}$ century mining, which is observed in the Beter indigenous towns near San Pedro de Atacama, both Spanish and criollo mining methods depended on the production of charcoal, made from wood extracted from the Prosopis groves. One effect of this was the deterioration of plant resources in the region. In fact, deforestation of the desert began to peak in the Calama basin at the turn of the $19^{\text {th }}$ century, when the first smelters were opened near a number of copper mines in the Chuquicamata area (Philippi 1853-54; Sutulov 1978).

The successful colonial production of copper outside of the Loa and Atacama basins paved the way for expansion on a scale never seen before, thanks to new European technologies: bellows, ore crushers, iron instruments, special ovens and the use of explosives. This led, in the early $19^{\text {th }}$ century, to more extensive exploration and control of ore extraction sites in barren pampas and sierras, 


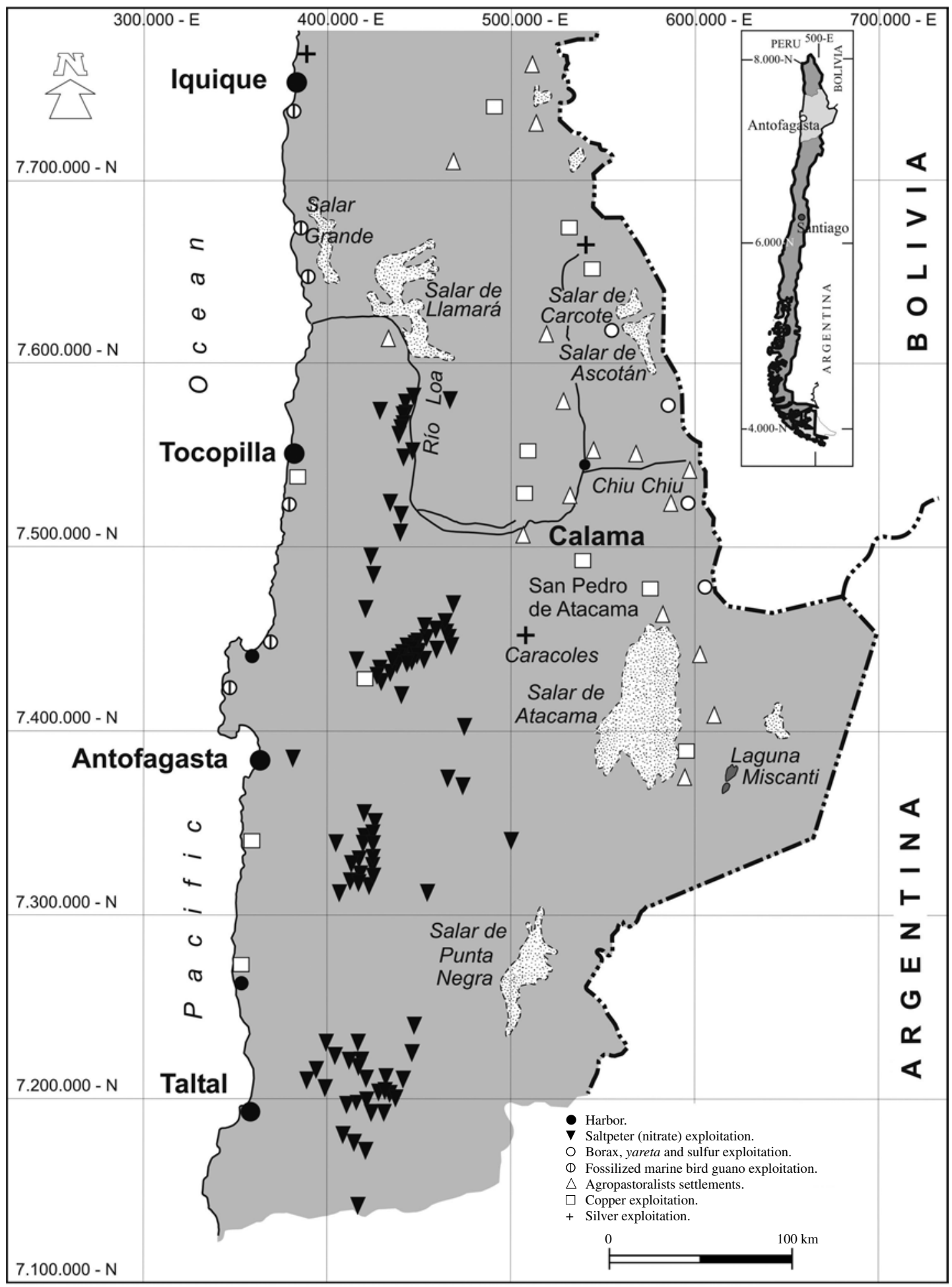

Figure 8. Late Holocene. Caracoles Occupational Pattern (AD 1,800-1,900/1,950).

Holoceno Tardío. Patrón ocupacional Caracoles (1.800-1.900/1.950 d.C.). 
ushering in a mining establishment separated from the land and sponsored by the wealthy class from the foothill oases and, later, by the elite of the newly established seaports (Bermúdez 1966). There is no doubt that the seeds of mining in the Atacama Desert, first indigenous and later Hispanic colonial, sprouted precisely at the end of the Beter pattern $\left(17^{\text {th }}\right.$ century $)$. At this time, a fine balance was achieved among several different things: the production of renewable natural resources and the commercialisation of coastal products, mule driving for coastal and trans-Andean exchange, copper extraction, and intermediary traffic of European goods disembarked at Cobija and transported to the city of Potosí and other mining centres in the central Altiplano region of Bolivia.

\section{Caracoles Occupational Pattern (AD 1,800-1,900/1,950)}

From the beginning of the $19^{\text {th }}$ century, indigenous-Spanish-criollo agriculture and livestock raising remained stable, while forage production (alfalfa) increased to support the intensification of mule transport to and from the coast and along trans-Andean routes, tied into mining exploration and operations.

Once the initial small scale copper mines of Chuquicamata were under development and the rich silver veins at Caracoles were discovered, there was a strong push to identify new deposits. Mules were used for these expeditions, which explored the vast barren expanses of the Atacama Desert (Labastie 1901; Sutulov 1978). A new social establishment emerged, from the coastline to the inland oases, around the infrastructure supporting this exploratory traffic. Mining entrepreneurs pressed local indigenous people to supply labour for the 300 mines at Chuquicamata (1898) and Caracoles (1870), to the detriment of indigenous farming and animal husbandry. At this time, the indigenous and mestiza communities began to migrate to the intermediate desert depression close to the deposits of copper, silver and sodium nitrate (known as saltpeter or salitre), setting up the first mining camps on the periphery of the operations. These occupational settlements were modeled after traditional ones and multiplied from 1866 onwards with the discovery of sodium nitrate on the barren pampa near Antofagasta. This attracted rural inhabitants from further south, as well as local indigenous people and foreigners, who were drawn by sodium nitrate operations to live in the first saltpeter "offices" or towns.

This unprecedented situation was unfolding in the most inhospitable lowlands of the desert, where numerous settlements were founded near mines equipped with sophisticated technology developed during the industrial revolution and imported from England. Four concentrations of "offices" (mining towns) were registered in the pampas between Taltal, Antofagasta and María Elena, each connected to a nearby seaport where eventually the cities of Antofagasta, Taltal, Tocopilla and Iquique would grow (Figure 8). The arrival in the saltpeter pampa of foreign labourers from the southern Atacama Desert valleys and from neighbouring ports and inland oases, as well as migrations from the Peruvian and Bolivian Andes, was sustained by the arrival of capital, entrepreneurs, engineers and European technicians, mainly from England, who built a modern, cosmopolitan industrial complex that culminated in the construction of the first railway lines (1872). These railroads eased the intense flow of road traffic from the saltpetre mines to the ports, where they connected with an intercontinental maritime shipping network (Contador 1983). Thus, the intermediate depression directly east of the Coastal Mountains was occupied on an unprecedented scale. This increasingly dense population required food, some of which was unloaded at the ports and railway stations and then transported to the pampa, while some was brought from the inland oases and valleys.

On the other hand, the total lack of local water required for the lixiviation of crude sodium nitrate led to its extraction from the Loa River and from wells built with the new British technology. This was the beginning of a dramatic shift in the use of water resources in the region, which caused the decline of indigenous agricultural productivity. In the sea ports, however, the problem of drinking water supply from the mid $19^{\text {th }}$ century onwards was solved by means of seawater desalinisation plants, remarkable initiatives that were discontinued in the $20^{\text {th }}$ century and have returned only slowly to Antofagasta most recently.

This period also witnessed the extraction of natural copper along the coast, as well as fossilized guano from marine bird deposits. The substance was located in paleodeposits on coastal reefs and was sold as a natural fertiliser. Extractive activities at these "covaderas" (guano deposits) on the desert coast had 
taken place since pre-Hispanic times, and continued into colonial times and beyond. The most intensive operations were located around the Departamento Litoral de Cobija (then part of Bolivia) and along the Tarapaca coastline (then part of Peru). These were regulated from 1824 onwards and peaked between 1874 and 1879, remaining in operation until the end of the $19^{\text {th }}$ century (Zolezzi 1993).

Labourers flocked to the pampa from Chile, Peru and Bolivia, to work alongside the coolie workforce brought from China by the British as part of their foreign expansion. In the areas around the coastal mines, guaneras, and moist areas boasting forage, small settlements began to emerge, inhabited by descendents of the Chango and Camanchaca peoples, survivors of the pre-Hispanic period who still practiced fishing and shellfish gathering using native techniques and materials such as wicker baskets and sea-lion skin rafts (Núñez 1986). These low-density occupations gradually grew into outlying towns on the edges of the saltpetre ports and expanding copper mines.

On the coast, local and foreign populations increased throughout the $19^{\text {th }}$ century, drawn there by the saltpetre industry, an increase that was proportional to the rapid proliferation of settlements established in the intermediate depression.

The large-scale mining industry depended on the use of imported fuel, given its unavailability in the Atacama Desert. Indeed, consignments of wood sent to Caracoles and logging for domestic and industrial use could not sustainably meet the region's growing needs and led to a sharp deterioration in local natural resources (Philippi 1853-54). The increased need for fuel for mining and other industries required the transportation of coal and oil from Central and Southern Chile, which was unloaded in desert seaports before being shipped to the saltpetre offices.

These fuels replaced the use of forest resources and the widespread extraction of cacti and yareta, a resinous plant found at high altitudes that burns at a high temperature. This plant was purchased in private business dealings from Andean people living near its natural habitat (e.g., Caspana) and was used as fuel by the Chilex Exploration Company of Chuquicamata (1913). For this purpose, motorized vehicles ascended to the Altiplano for extraction activities at around 4,000-5,000 masl, exacerbating the eradication of traditional agrarian and herding practices. At the same time, sulfur, another raw material required by the copper mining companies, was being extracted from the high mountain reaches.

By the end of the $19^{\text {th }}$ century, the now-large saltpetre population required large consignments of food and major infrastructure works, which were supplied by a railway and shipping network -made up of trains, Kepler sailing ships and Chilean steamboats- that carried ore and saltpetre from the mines to nearby seaports and abroad, bringing back an abundance of imported goods. This modern technological-industrial cluster was directly connected with merchant fleets, which turned ports and saltpetre offices from Taltal to Pisagua into lively places with high concentrations of multiethnic and peasant populations, all within a process of proletarianization that included emigrants from neighbouring countries and Europe. This intensification of pioneer capitalism provoked the first social tensions associated with emergence of labour unions worldwide (Recabarren 1954). In other words, the saltpetre area, which was previously uninhabited (except for the coast, where there were some indigenous villages and one or two Hispanic ports such as Loa or Cobija), saw an unexpected change in its occupation pattern at the end of the $19^{\text {th }}$ century. The Province of Antofagasta alone had 13 saltpeter towns and, including the coastal inhabitants, a total population of 33,636 (Contador 1983) (Figure 8).

Productive activities on the coast at this time were mainly small-scale near-shore activities, and had little impact on the nearby seaports. However, over time the people began to replace their traditional rafts with larger vessels, orienting production to the needs of the saltpeter ports (Núñez 1980).

Unlike previous patterns, these occupations were closer to the Pacific Ocean, concentrating political and administrative power there as $19^{\text {th }}$ century modernity led to a more urban way of life. The towns were furnished with imported goods and left behind an architectural legacy that remains to this day in the homes and official buildings of the times. These constructions emerged rapidly by means of the lumber and cane shipped from abroad as ballast, and their most notable examples can still be observed in the older buildings standing near the port facilities (Contador 1983). These coastal settlements were built near the first saltpeter ports as efficient and attractive urban centers, quite separate from the more industrial saltpeter towns located in the intermediate pampa. On the coast, water was 
traditionally obtained from springs and transported by sea. However, desalinization gradually became the sole source of drinking water, requiring fuel to feed the distillation process whereby salt water was transformed into freshwater. This method was not only a British technological response, recently available worldwide, but also proof of a decision not to expropriate nearby indigenous and criollo water supplies. Practices in the saltpeter pampa region reflect a policy that was equally considerate of the farming communities living in the oases and inland valleys. There, new water well technology fulfilled the same purpose. This concern allowed more harmonious ties between the saltpeter towns and local farmers and herders. However, the large desert cities were highly attractive (Bermúdez 1963) and drew agricultural workers away from the Andean region to the lively, modern urban centres of the Loa and Atacama basins, both in the pampa and on the coast. In fact, the workforce in this pioneer era came from the Andes to work in the small copper mines, ports, the Caracoles silver deposits, in the coastal guano deposits and, of course, in the numerous saltpeter mines around the ports of Taltal, Antofagasta and inland from Tocopilla.

On the other hand, the densely populated ports and mining towns opened up unexpected new markets for agricultural produce and animal forage produced in the oases and valleys of the Atacama region. This meant that a significant portion of the indigenous population remained in their traditional zones to supply meat, wheat, fruit, corn, wood and alfalfa to these markets. Particularly important was the transport and care of Argentine cattle and horses destined for consumption by the saltpeter and port markets and, of course, for use as beasts of burden, moving goods to and from the mining towns and across the desert.

The former indigenous economy that had been concentrated in the oases and valleys of the Loa and Atacama basins from pre-Hispanic times managed to survive without socio-political power even under the Hispanic-criollo economy. Until the end of the $19^{\text {th }}$ century, indigenous groups were a marginal presence, segregated and discriminated against for their identity as Bolivians. After the War of the Pacific, they were "integrated," granted Chilean citizenship under a sudden ideological shift known as the "Chileanization" of the Atacama Desert (González 2005).
However, even during these times the local indigenous, mestizo and criollo settlements, rooted in agricultural and livestock production and cattle driving, had managed to mould a cultural landscape, an identity based in the midlands and highlands of the Loa and Atacama basins near the Bolivian and Argentinean borders. This more rural, conservative scene contrasted with the urban industrial panorama, which was consolidated by the British industrial revolution and concentrated its modern impact in the desert lowlands and the saltpeter ports and towns, where modes of living and producing were entirely different.

Many of the Andean people were attracted to these modern places by their expressions of progress (electricity and movie cinemas, for example) and even exchanged their ponchos for suits and traditional bartering practices for monthly salaries, putting down roots in the new urban landscape of the saltpeter industry and seaports.

Thus, as this occupational pattern comes to a close, two opposed yet complementary "worlds" are in evidence: To the east was the rural ethnic and criollo Andean population, considered "backward," while to the west were the urban, multiethnic, industrial, local and cosmopolitan towns, viewed as "progressive," sustained in a complex intermeshed relationship with the local population. The new large scale mining industry certainly led to more opportunities to inhabit the Atacama Desert, this time more intensively from the Andean foothills to the Pacific Ocean. This large territory can be divided into four bands: the coastal ports, the intermediate saltpeter pampa, its eastern copper -and silver- bearing edge, and the inland valleys, with their agricultural resources.

\section{Chuquicamata Occupational Pattern (1,900/1,950 to the Present Day)}

At the beginning of the twentieth century the saltpeter ports and establishments grew in population, leading to a high occupational density in the lowlands of the Desert (Figure 9). In 1890, fortysix saltpeter establishments were operating in the north of the country with a total of 14,215 workers. However, by 1914 this number had already increased to 118,000 , with 46,470 workers in Antofagasta alone, and in the zones close to Central, Boquete and Aguas Blancas (Hernández 1930). Between El Toco, inland from Tocopilla, and Taltal, eighty-five 


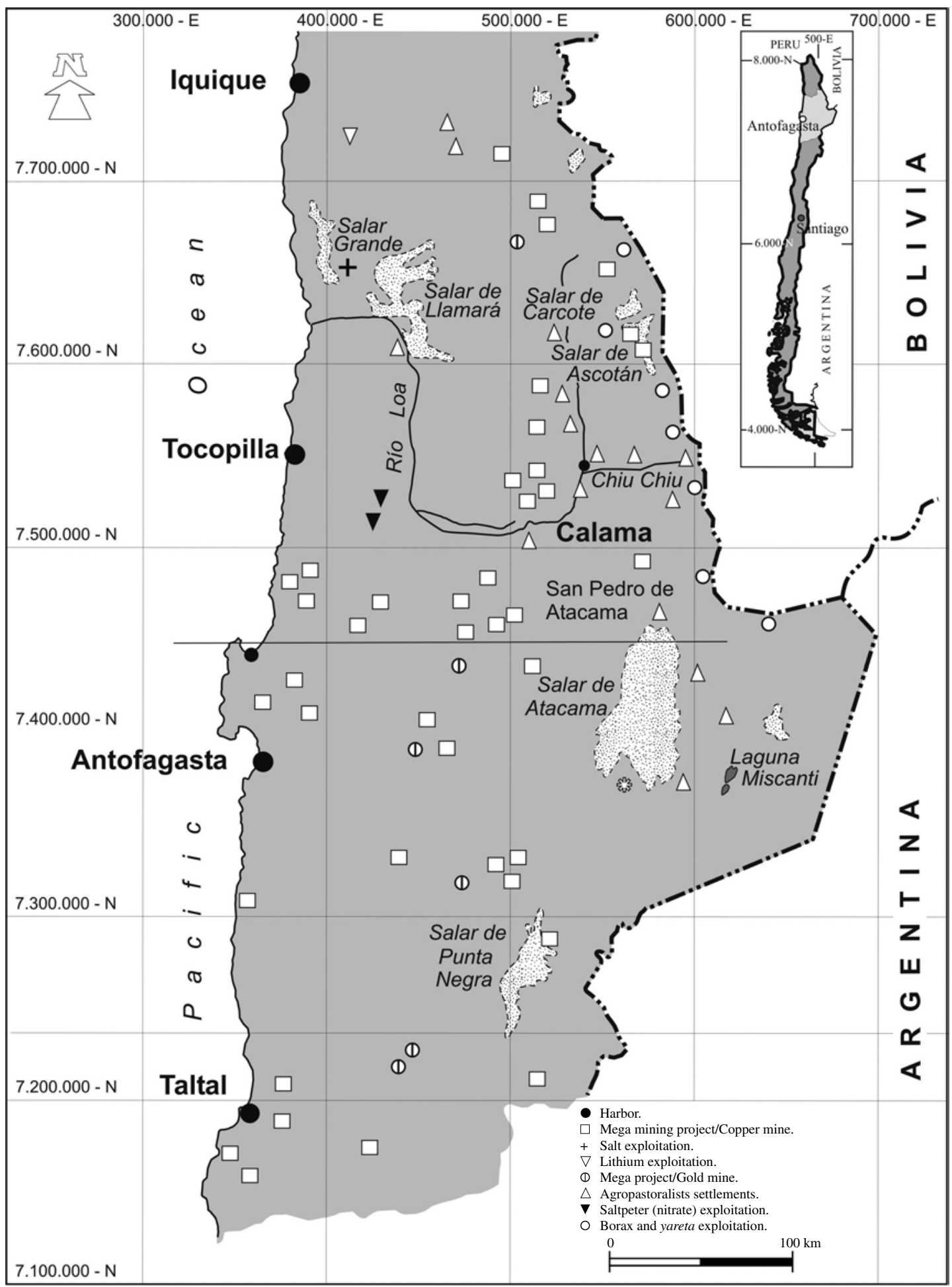

Figure 9. Late Holocene. Chuquicamata occupational pattern (AD 1,900/1,950 hasta el presente). Holoceno Tardío. Patrón ocupacional Chuquicamata (1.900/1.950 d.C. hasta el presente). 
settlements have been identified belonging to the saltpeter cycle. These settlements paid exportation royalties, which averaged $42.82 \%$ of the regular national revenues (Hernández 1930). This situation changed abruptly in 1945, when the world saltpeter market upon which the national economy depended was brought to a standstill by the European invention of artificial nitrates, a low-cost fertiliser. As a result of this, the saltpeter towns gradually closed down and the ports of Tocopilla and Taltal lost much of their importance.

The retreat of saltpeter capital and the return of the workers to their cities and valleys of origin, in both Bolivia and Central Chile, gave rise to the most significant social crisis of this occupational sequence. Today, the Maria Elena mine stands as the only saltpeter mine that managed to survive the sodium nitrate bust, and the train line that transported the saltpeter to the port of Tocopilla still runs, with new iodine and sodium nitrate projects emerging that re-utilize the "cakes" leftover from the saltpeter production process. These circular platforms mark the location of the former saltpetre town, along with its ruined buildings, waste dumps and cemeteries, making this place one of the most important industrial archaeological reserves in the South American desert environment (Vilches et al. 2008).

As the silver veins of Caracoles were exhausted and salpeter extraction peaked copper mining began to proliferate between the Andes and the Pacific coast. It began in remote mines with limited production to gradually grow into a major force as copper was used more and more in industrial processes and electrification in the developed world. Beginning in the early $20^{\text {th }}$ century, copper attracted large concentrations of (mainly US) capital and technology in the area of Chuquicamata (Sutulov 1978). The mining methods of the transnational companies led to an unusual, unprecedented concentration of human occupation of the nearby city of Calama, which until that time had been a rural outpost. This growth was also tied to other mining efforts emerging at the same time as the Chuquicamata copper mines. Following the desert mining tradition, the workers and their families were housed in Chuquicamata, a town administered and organised according to the standards of the transnational company that owned it. The company followed a 'sectoring' system that separated employees according to social and professional standing. At present, surface copper extraction is no longer sufficient and extraction technology has enabled the exploration of deep underground deposits.

Although the era of the first mega projects had begun early in Chuquicamata, the pattern of expansion there was an isolated case, as illustrated by the smaller projects that followed, at Mantos Blancos, Michilla and Lomas Bayas, among others, located at around 3,000 masl in the Coastal Mountains. The mining communities gradually began to adapt to the lowlands, this time with the added benefit of electricity generated by power plants in Tocopilla and Antofagasta. Other fuel (including oil) was unloaded at the seaports and transported by a rail line now at the service of the copper boom. The port and growing city of Antofagasta became the principal gateway for copper exported from Chile to the rest of the world, and this business brought a notable expansion of commerce and services here. Indeed, the population of 3,000 living in the city in the $19^{\text {th }}$ century has swelled to over 300,000 inhabitants today (Contador 1983). After the saltpeter crisis, however, Chile's other desert ports became obsolete, though many now function as commercial centres, fishing wharfs, docks and service areas, opening up broader opportunities beyond their past role as mining ports.

In this period, the coastal area saw the development of more specialised and technological fishing practices, involving larger fleets associated with the fishmeal industry. There has also been a remarkable increase in shellfish collection due to new diving techniques. Trans-Chilean and international coastal shipping, duty-free zones, small-scale fishing and the large-scale fishing industry typical of this period, as well as fish and shellfish farming, are all unequivocal signs of progress, and point to even more innovations in future as Chile's socio-economic projections continue (E. González 1996).

Today, there has been a major shift in the organization of the coastal territory, as large mining companies efficiently transfer copper concentrate via trans-desert pipelines to ad hoc facilities far removed from the usual ports and cities. In addition, human occupations have been eliminated due to the extremely high levels of pollution concentrated in mining operations, such as in Chuquicamata. Now, mining settlements are always located outside the areas of extraction (as in the Collahuasi Project), or in private enclaves near the ports of Antofagasta, Calama and Iquique, where they have revitalized post-saltpetre urban developments. The occupation 
of some former mining installations and adjoining residential areas close to mining production residuals and continued pollution is one of the most critical environmental problems faced by the towns located next to mining operations in the desert region (e.g., Calama).

Beginning in the 1980s, further developments in the industry included the use of remote sensing technologies to detect new copper deposits. This led to another revolution as large mineral deposits were discovered. After the nationalisation of Chuquicamata (1971), these projects have been developed through a partnership of trans-national capital and the Chilean Government (Espinoza and Núñez 1992).

The development of Chile's economy around the large-scale mining industry, and associated with urban expansion, derived from a State policy introduced by the Military Government (post 1973). But this neo-liberal, open market economic model to attract foreign investment continued after Chile's return to democratic rule. Under this model, the mining industry achieved unprecedented growth that led to a breakdown of society's relationship with the environment. This resulted in the total disconnection of human activities with renewable natural resources according to the principles of Sustainable Development (UNCED 1987).

At the same time, throughout the $20^{\text {th }}$ century and into the $21^{\text {st }}$, the implementation of mining mega-projects has led to the growth of mining cities such as Calama, Antofagasta and Iquique, among others, as mine employees' move there to live with their families. However, another significant portion of these workers maintain homes in Central and Southern Chile and migrate to work in the mines. Such mobility patterns could lead to serious social consequences.

At present, there are several mining megaprojects operating in the second region (El Abra, Radomiro Tomic, Chuquicamata, Mantos Blancos, Michilla, Zaldivar, Escondida, Guanaco, Spence, Lomas Baya, and El Tesoro, to name the largest), as well as two gold mines, Proyecto Fortuna and el Peñón. Upcoming projects include Mansa Mina, Toki-Quetena, and Gaby, with other copper bearing developments slated to be opened as well. One salpeter office still remains (María Elena - Soquimich), and there are two developments of lithium and salt in the Atacama Salt Flat (SOQUIMICH), and one of cement (INACESA).
In these cases, workers live in family residences in nearby cities such as Calama and Antofagasta, following the supply chain of goods and power that brings required materials from the outside to the desert. However, the urban infrastructure is still not adequate or stable enough to meet the needs of such highly concentrated populations. The active circulation of people between the industrial mining centres, coupled with the recent emphasis on connectivity between urban, rural and tourist destinations has begun to limit the "insular" nature of the Desert settlements. This process has been further accentuated by the so-called "bioceanic corridors" (Granic et al. 1995). Although the population during this occupational pattern is lower than during the saltpetre period, it is more concentrated, in the coastal cities and the single inland city of Calama. Meanwhile the large copper mines that underpin the national economy are now limited to focal points that have overturned the former pattern, and instead, have moved mining towns away from the operations they serve, as shown in the attached graph (Figure 9) Deposits of other minerals, such as borax and lithium, are situated near rural, indigenous farming and herding lands, which of course implies many concerns that have been detected early (Chong 1969).

This overlap or proximity of mining megaprojects over herding and farming lands has led to conflicts and re-adaptation strategies as these industries venture for the first time into areas that have traditionally been managed by the indigenous peasant communities, which now are in a legal position to demand their rights (Barros 2004).

Nevertheless, during the current occupational pattern, with its signs of critical rural under- population associated with disproportionate urban growth, it has been observed that the industrial water deficit has been addressed in a way quite unlike the past approach. This new approach emerged from the huge increase in the amount of water required for the region's many copper lixiviation plants. Paradoxically, although precise limits have been placed on the drilling of subsistence wells, the indiscriminate installation of industrial wells falls into a legal grey area (see the Water Code 1981). In effect, then, water from the desert is now being sold by private companies that specialise in extracting water to sell to companies that require it. As a result, there is friction between the interests of mining companies and local communities that 
depend on these natural resources (Alonso et al. 2003; Barros 2004; Romero 2002).

The Chilean Water Code (1981) contains three major provisions: (a) the privatisation of water use through ownership rights, (b) the application of free market practices, making water a tradable good and (c) the disconnection of water resources from land productivity. Whilst in theory the neo-liberal economic framework has earned positive evaluations, the empirical data shows that the model leads to a significant increase in resource deficits and other large negative impacts. In this sense, and with regard to water rights, the social and environmental costs have not been considered or regulated, making the Chilean model incompatible with integrated water resource management (Bauer 2004).

It is surprising how different the approaches to water use are in these two most recent occupational patterns. Before 1900, the British salpeter companies with their advanced technology did not use river water but dug wells downriver from farming and livestock centres. Now, in accordance with current legislation and following the example of the US at Chuquicamata, which piped water from the River Loa at its source, socially damaging practices are the norm (GARHIN 1994). Clearly, such practices have directly affected and harmed the indigenous communities that have cultivated the Loa and Atacama river basins. Despite legal instruments that protect the ancestral resources of these communities, there is still no recognition of their customary rights, which pre-date the expansion of modern mining in the region.

The magnetic attraction of cities and the launching of mining mega-projects have definitely been partly responsible for the abandonment of traditional indigenous towns, which have become ritual places centred around churches, where descendants of the original residents come to participate in traditional celebrations at certain times of the year. Added to this is the deterioration of farming and herding areas due to the diminishing workforce and water depletion (Castro et al. 2004). Although Chile's economic prosperity certainly depends on its copper resources, the Government still has not managed to balance the interests of communities living near these mining mega-projects, and the economic objectives of these initiatives (Romero 2002). In this critical scenario, disputes over water resources remain a major concern. Although it is not yet legal to divert river courses, the indiscriminate proliferation of industrial wells is authorized. How can such water removal not affect the pasturelands, wetlands and foothill oases? What is the real potential of groundwater, whether fossil or not? What is the real contribution of the desalinating and water recycling plants? How much water should be allocated to mining mega projects and cities? And how much to the villages and people that depend on agriculture and livestock production?

\section{Conclusions}

Up to now, mining has been seen as the inescapable 'destiny' of Chile's north, and this industry has sustained the relatively recent settlement of the Atacama Desert far beyond the level achieved by agrarian, herding and fishing ways of life. However, this tendency could change if, as is usual in an average timeframe of 40 years, the available mineral resources are exhausted or are made obsolete by new discoveries or technological developments. In such a scenario, it is unclear how subsequent human occupations will fare if, in the meantime, no research is carried out to explore alternative forms of occupation tied to renewable natural resources and undiscovered mineral deposits. In such analyses, care should be taken not to over-scale the current model of raw material exports, mainly from mining and metallurgy, which has sustained the occupational sequence of the past two centuries.

From this perspective, the importance of the socio-economic, technological and productive benefits derived from the region's geological resources cannot be denied. These have also been associated with greater occupational complexity in the ports and cities that emerged during the saltpeter cycle along the coast and in the inland pampa areas, not to mention the mining settlements located east of the intermediate depression of the deep desert.

On the other hand, the indigenous and colonial agricultural and mercantile resources that are more associated with the Andean region went from playing a dominant role to the more marginal one of 'rural relics'. These lacked the major innovations that would have enabled the continuity and optimization of agricultural and livestock production practices dating back to pre-Hispanic and Colonial times. The European industrial innovations, brought as part of the foreign intervention in arid areas beginning in the mid- $19^{\text {th }}$ century, made the Atacama Desert one of the most attractive focal points for capital 
investment, especially given the politically favourable environment, and marked the region's destiny as a large-scale mining venue. While this situation has been advantageous, it also has had some serious repercussions, judging by the growing deterioration of cultures and agrarian, herding, fishing and maritime resources, which are longer-lasting and, therefore, deserve to be recovered.

The large-scale use of the extremely limited water resources found in hyper-arid desert environments would affect all human occupations and their respective socio-economic projects. Given this reality, the present critical deficit of water in the region calls for innovative strategies such as seawater desalination plants, larger and better treatment plants for industrial and domestic wastewater, and water pipelines from neighbouring countries. Longer term initiatives may include sophisticated engineering projects to make use of the water from the Pacific cloudbanks (camanchaca) that are present in front of the Coastal Mountains (Ramírez 1980). At present, it is clear that the lack of knowledge of quantitative and dynamic aspects of water availability in the desert basins makes it impossible to ensure their sustainability or to balance the needs of mining projects with those of citizens (2007).

To date, unlike in other countries, Chile's desert coast has not been able to attract large settlements founded on the extraction of marine resources, despite the stability achieved by pre-Hispanic and Hispanic settlements. So far, there has been little interest in the large scale incorporation of fish and seafood into the population's diet and, therefore, technological innovations in this area have been minimal (J.A. González 1996). Such innovations would allow for a gradual shift from small scale fishing communities to more specialised ones that are capable of maintaining balance in the ecosystem. These would include the implementation of 'reserved' and 'managed' areas within a framework of sound resource use, based on fishing and gathering cotos. Such developments have recently been encouraged along the desert coast, with fish farms already established, calling to mind the great shift in agricultural production generated by Neolithic innovations.

On the other hand, current fishing industry practices need to be re-oriented towards human consumption rather than animal feed. It is generally acknowledged today that the marine ecosystem is on the verge of collapse due to the failure to measure and delimit different reserve areas and zones suitable for small scale and industrial fishing.

It is no mystery to anyone that the sea not only has become the backyard dump for contaminated urban waste, but has also begun a process of desertification as its resources 'dry up,' a process that has been witnessed by recent generations as the disappearance of coastal fish species. The impact of contamination on fishing activity has not been addressed through regulations, nor are there sufficient international agreements in place for managing international waters.

One of the most illustrative examples of macrospatial contamination from copper mining derives from the Salvador mines, whose toxic tailing waste affects not only the intermediate valley but also the beach and marine area surrounding the port of Chañaral. This critical imbalance between the short-term success of the mining industry and the diminishment of renewable natural resources, an issue lacking in research with a few notable exceptions (El Mercurio 2007), has exposed an evident crisis associated with growing aridity and global climatic anomalies. In fact, if pending international agreements to control global warming are not put into effect, the fragile Atacama Desert ecosystem could unexpectedly collapse in the face of the immense climatic variability projected for the present century. Information currently available indicates that, if effective transnational policies are not achieved within the next 70 years, climate change will directly affect the desert environments of the north of Chile (CONAMA 2006). This scenario would bring about a new hydrological cycle, with greater evaporation due to the increased temperature and shorter, rainier (and stormier) summers. At the same time, mountain ice and snow will retreat and surface water and groundwater will diminish to critical levels. The oases would shrink as the salt flats expand. The destructive effects of seasonal rivers would interfere with agricultural practices and the decrease in water flow in winter would lead to the deterioration of productive land. The temperature increase expected would not only affect the inhabitants of the Desert, but also cause the disappearance of cold-water marine species, including the plants upon which edible shellfish feed, thereby initiating a processes of extinction in a scenario quite different from the present one. In short, the effects on the desert environments of northern Chile would be significant (Boulanger et al. 2010). 
These imbalances could seriously alter the long-term habitability of the desert and, therefore, hinder the survival of a society that, notwithstanding its environmentally-rooted identity (J.A. González 1996), has not managed to develop a genuine "desert culture" in recent occupational patterns. The modern day societies of the Atacama Desert are still a long way from achieving the fine balance required between stable, continuous human occupation, the responsible use of these barren areas and the known and hidden resources they contain. The conservation of habitats and the survival of humans living in fragile ecosystems will depend on such intelligent interaction and in this case, the interaction will ultimately require a series of urgent cultural, technical, political and ethical responses (UNCED 1981).

Acknowledgements: We are greatful to the anonymous referees who provided helpful suggestions that improved the article. We would also thank those who helped to improve the English version of the manuscript. Finally to FONDECYT-projects 1020316 and 1070040, and to Vicerrectoría de Investigaciones of the Universidad Católica del Norte for supporting the first author's historical research during his sabbatical year.

\section{References Cited}

Agüero, C.

2005 Aproximación al asentamiento humano temprano en los oasis de San Pedro de Atacama. Estudios Atacameños 30:29-60.

Alonso, H., L. Núñez, and P. Pourrut

2003 Les Oasis du Desert d'Atacama. Gestion de l'eau et Défi du Temps. L'Harmattan, París.

Aschero, C.

2000 El poblamiento del territorio. En Nueva Historia Argentina, los Pueblos Originarios y la Conquista, edited by M. Tarragó, pp. 17-60. Editorial Sudamericana, Buenos Aires.

Barros, A.

2004 Crónica de una etnia anunciada: nuevas perspectivas de investigación a 10 años de vigencia de la Ley Indígena en San Pedro de Atacama. Estudios Atacameños 27:139168.

Bauer, C.J.

2004 Results of Chilean water markets: Empirical research since 1990. Water Resources Research 40:1-11.

Benavente, A.

1984 Chiu Chiu 200: Una comunidad de pastores tempranos en la provincia del Loa (II Región). Actas del IX Congreso Nacional de Arqueología Chilena, pp. 75-94, La Serena.

Berenguer, J.

1998 La iconografía del poder en Tiwanaku y su rol en la integración de zonas de frontera. Boletín del Museo Chileno de Arte Precolombino 17:19-37.

2004 Caravanas, Interacción y Cambio en el Desierto de Atacama. Ediciones Sirawi, Santiago.

Bermúdez, O.

1963 Historia del Salitre desde sus orígenes hasta la Guerra del Pacífico. Universidad de Chile, Santiago.

1966 Orígenes Históricos de Antofagasta. Editorial Universitaria, Santiago.

Binford, M.W., A.L. Kolata, M. Brenner, J. Janusek, M.B. Abbott, and J.H. Curtis

1997 Climate variations and the rise and fall of an Andean civilization. Quaternary Research 47:235-248.

Boulanger, J.P, G. Grasseur, A.F. Carril, M. de Castro, N. Degallier, C. Ereño, H. Le Treut, J.A. Marengo, C.G.
Menéndez, M.N. Núñez, O.C. Penalba, A.L. Rolla, M. Rusticucci, and R. Terra

2010 A Europe-South America network for climate change assessment and impact studies. Climatic Change 98:307329.

Bowman, I.

1924 Desert trails of Atacama. Special Publication American Geographical Society $N^{\circ} 5$, New York.

Capdeville, A.

1921 Notas acerca de la arqueología de Taltal. Boletín de la Academia Nacional de Historia 2(5), Quito.

Cartajena, I., L. Núñez, and M. Grosjean

2005 Animal utilization and camelid domestication in the Atacama Desert: 13.000-3.500 cal. B.P. Paper presented at the 2 nd. Southern Desert Conference: Human-environment interaction in Southern Hemisphere Desert. Past, Present and Future, Arica.

2007 Camelid domestication in the western slope of the Puna de Atacama, Northern Chile. Anthropozoologica 42:155-173. Castelleti, J.

2005 Compilado final de actividades de sondeo y rescate Proyecto Construcción y Mejoramiento ruta 1 tramo Taltal-Paposo. Tomo I y II Convenio Dirección Nacional de Vialidad-Cuerpo Militar del Trabajo.

Castro, V.

1994 Algunas reflexiones sobre los periodos tardíos en el Norte Grande de Chile. Actas del XIII Congreso Nacional de Arqueología Chilena, pp. 143-145, Universidad de Antofagasta, Antofagasta.

Castro, V., C. Aldunate, and V. Varela

2004 Ocupación humana del paisaje desértico de Atacama, Región de Antofagasta. ARQ 57:14-17, Santiago.

CONAMA

2006 Estudio de la variabilidad climática en Chile para el siglo XXI. Study conducted by the Departamento de Geofísica, Facultad de Ciencias Físicas y Matemáticas, Universidad de Chile, Santiago.

Contador, A.

1983 Hombre y Cabildo en los orígenes Históricos de la Ciudad de Antofagasta. Universidad del Norte, Antofagasta. 
Chong, G.

1969 Recursos no metálicos de la Provincia de Antofagasta. Norte 3(1):33-46. Universidad del Norte, Antofagasta.

El Mercurio

2007 Científicos de la UCN buscan agua en el Desierto. March 11, 2007, Antofagasta.

Espinoza, S., and L. Núñez

1992 Aprovechamiento minero: Chuquicamata. In Iberoamérica desde el Espacio, pp. 277-280. Editorial Sociedad Estatal V Centenario, Lunwerg Editores S.A., Spain.

GARHIN

1994 Universidad Católica del Norte. Programa de gestión ambiental de recursos hídricos en zonas áridas y su litoral. Informe Final, Antofagasta.

González, J.A.

1996 Elementos de discusión para definir la identidad cultural del Norte Grande. Norte 1(1):47-61. Universidad Católica del Norte, Antofagasta.

2005 Chile y Bolivia, 1810-2000. In Argentina, Chile y sus Vecinos. Ed. P. Lacoste, Colección Cono Sur, Tomo I, Argentina.

González, E.

1996 La Universidad Católica del Norte y la investigación en ciencias del mar. In La Universidad Católica del Norte y el Desarrollo Regional Nortino, coordinated by J.A. González, pp. 143-159. Ediciones Universitarias, Antofagasta.

Granic, Y., R. Mella, and X. Ziede

1995 Importancia de los Corredores Bioceánicos en el Marco de la Integración entre los Países del Centro Oeste de Sudamérica y la Segunda Región de Chile. Thesis presented for the title of Journalist, Tomo I, Universidad José Santos Ossa, Antofagasta.

Grosjean, M., B. Messerli, C. Amman, M.A. Geyh, K. Graf, B. Jenny, K. Kammer, L. Núñez, H. Schreier, U. Schotterer, A. Schwalb, B. Valero-Garcés, and M. Vuille

1997 Holocene environmental changes in the Atacama Altiplano and Paleoclimate Implications. Bulletin de l'Institut Français d'Etudes Andines 24:585-594.

Grosjean, M., and L. Núñez

1994 Late glacial, early and middle Holocene environment human occupation and resource use in Atacama northern Chile. Geoarchaeology 9(4):271-286.

Grosjean, M., J. Leeuwe, W.O. van der Knaap, B. Ammann, W. Tanner, B. Messerli, L. Núñez, B. Valero-Garces, and H. Veith

2001 A $22,000{ }^{14} \mathrm{C}$ years B.P. sediment and pollen record of climate change of Laguna Miscanti $\left(23^{\circ} \mathrm{S}\right)$, Northern Chile. Global and Planetary Change 28:35-51.

Grosjean, M., L. Núñez, and I. Cartajena

2005a Paleoindian occupation of the Atacama Desert, Northern Chile. Journal of Quaternary Science 20(7-8):643-653.

2005b Cultural response to climate change in the Atacama Desert. In $23^{\circ}$ South: Archaeology and environmental history of the southern deserts, edited by M. Smith, and P. Hesse, pp. 156-171. National Museum of Australia, Canberra.

Grosjean, M., L. Núñez, I. Cartajena, and B. Messerli 1997 Mid-Holocene climate and culture change in the Atacama Desert, Northern Chile. Quaternary Research 48:239-246.
Grosjean, M., C. Santoro, L.G. Thompson, L. Núñez, and V. Standen 2007 Climate and culture change in the South Central Andes. In Climate Change and Cultural Dynamics: A Global Perspective on Mid-Holocene Transitions, edited by D.G. Anderson, K.A. Maasch, and D.H. Sandweiss, pp. 51-115. Academic Press, San Diego.

Grosjean, M., B. Valero Garcés, A. Schwalb, M. Geyh, B. Messerli, and K. Kelts

1996 Limnogeology of Laguna Miscanti: Evidence for Mid to Late Holocene moisture changes in the Altiplano (Northern Chile). Journal of Paleolimnology 16:1-21.

Hernández, R.

1930 El Salitre. Resumen histórico desde su descubrimiento y explotación. Asociación de Productores de Salitre en Chile, Valparaíso.

Hidalgo, J.

1981 Fechas coloniales de fundación de Toconao y urbanización de San Pedro de Atacama. Chungara 8:255-264.

Jackson, D., and C. Méndez

2005 Primeras ocupaciones humanas en la costa del Semiárido de Chile: Patrones de asentamientos y subsistencia. Actas XVI Congreso Nacional de Arqueología Chilena, pp. 493502, Tomé.

Labastie, F.

1901 Estudios sobre el Mineral de Caracoles. Imprenta, Litografía y Encuadernación Barcelona, Santiago.

Llagostera, A.

19799700 years of maritime subsistence on the Pacific: An analysis by beans bio indicators in the North of Chile. American Antiquity 44(2):309-324.

Llagostera, A., A.M. Barón, and L. Bravo

1984 Investigaciones arqueológicas en Tulor-1. Estudios Atacameños 7:133-151.

Llagostera, A., R. Weisner, G. Castillo, M. Cervellino, and M.A. Costa

1997 El complejo Huentelauquén bajo una perspectiva macroregional y multidisciplinaria. Contribución a la Arqueología 5:461-510, Copiapó.

Martínez, J.L.

1985 Información sobre el comercio de pescado seco entre Cobija y Potosí, hecha por el Corregidor de Atacama Don Juan de Segura (19 de julio de 1591). Cuadernos de Historia 5:161-171.

Martínez, J.L., V. Manríquez, and C. Sanhueza

1990 Asentamientos y recursos en Atacama (s. XVII). In Economía y Comercio en América Hispana. Serie Nuevo Mundo: Cinco Siglos 5:13-61, editado por G. Bravo. Universidad de Chile, Santiago.

Marquet P.A., F. Bozinovic, G.A. Bradshaw, C. Cornelius, H. González, J.R. Gutiérrez, E. Hajek, J.A. Lagos, F. LópezCortéz, L. Núñez, E.F. Rosello, C. Santoro, H. Samaniego, V.G. Standen, J.C. Torres-Mura, and F.M. Jaksic 1998 Los ecosistemas del Desierto de Atacama y área andina adyacente en el norte de Chile. Revista Chilena de Historia Natural 71:593-617.

Mengoni, G., and H.D. Yacobaccio

2006 The domestication of South American camelids. A view from the south central Andes. In Documenting Domestication, New Genetic and Archaeological Paradigms, edited by M.A. Zedar, D.G. Bradley, E. Emswiller, and B.D. Smith, pp. 228-244. University of California Press, Berkeley. 
Moragas, C.

1982 Túmulos funerarios de la costa sur de Tocopilla (Cobija), II Región. Chungara 9:152-173.

Muñoz, I., and J. Chacama

1993 Patrón de asentamiento y cronología de Acha-2. In Acha-2 y los Orígenes del Poblamiento Humano en Arica, edited by I. Muñoz, B. Arriaza, and A. Aufderheide, pp. 21-46. Ediciones Universidad de Tarpacá, Santiago.

Núñez, L.

1971 Secuencia y cambio en los asentamientos humanos de la desembocadura del río Loa. Boletín de la Universidad de Chile 112:3-25.

1980 Cazadores tempranos en los Andes Meridionales. Evaluación cronológica de las industrias líticas del norte de Chile. Boletín de Antropología Americana 2:87-120. Instituto Panamericano de Geografía e Historia, México.

1983a Paleoindian and Archaic cultural Periods in the arid and semiarid regions of Northern Chile. Advances in World Archaeology II, pp. 161-201. Academic Press, New York. 1983b Paleoindio y Arcaico en Chile: Diversidad, Secuencia y Procesos. Series Monográficas 3, Editorial Cuicuilco, México.

1984 Secuencia de asentamientos del área de Taltal. Futuro 8:28-76.

1986 Balsas prehistóricas del litoral chileno: grupos, funciones y secuencia. Boletín Museo Chileno de Arte Precolombino $1: 35$

1992a Ocupación arcaica en la Puna de Atacama: secuencia, movilidad y cambio. In Prehistoria Sudamericana: Nuevas Perspectivas, edited by B.J. Meggers, pp. 283-307. Taraxacum, Washington.

1992b Cultura y Conflicto en los Oasis de San Pedro de Atacama. Editorial Universitaria, Santiago.

1999a Valoración minero-metalúrgica circumpuneña: menas y mineros para el inka rey. Estudios Atacameños 18:40-65. 1999b Fase Tilocalar: nuevas evidencias formativas en la Puna de Atacama (Norte de Chile). In Formativo Sudamericano, edited by P. Ledergerber-Crespo, pp. 227-242. Smithsonian Institution, Washington.

2005 La naturaleza de la expansión aldeana durante el formativo tardío en la cuenca de Atacama. Chungara Revista de Antropología Chilena 37:165-193.

Núñez, L., R. Casamiquela, V. Schiappacasse, H. Niemeyer, and C. Villagrán

1994 Cuenca de Tagua Tagua en Chile: el ambiente del pleistoceno y ocupaciones humanas. Revista Chilena de Historia Natural 67:503-519.

Núñez, L., and T. Dillehay

1979 Movilidad giratoria, Armonía Social y Desarrollo en los Andes Meridionales: Patrones de Tráfico e Interacción Económica. Universidad del Norte, Antofagasta.

Núñez, L., and M. Grosjean

2003 Biodiversity and Human impact during the last 11.000 years in North-Central Chile. Ecological Studies How Landscapes Change 182:8-17. Springer-Verlag, Berlin-Heidelberg.

Núñez, L., M. Grosjean, and I. Cartajena

1999 Un ecorefugio oportunístico en la Puna de Atacama durante eventos áridos del Holoceno Medio. Estudios Atacameños 17:125-174.

2002 Human occupations and climate change in the Puna de Atacama, Chile. Science 298:821-824.
2005 The expansion of the Inka Empire into the Atacama Desert. In $23^{\circ}$ Archaeology Environmental History of the Southern Desert, edited by M. Smith, and P. Hesse, pp. 324332. National Museum of Australia, Canberra.

Núñez, L., I. Cartajena, C. Carrasco, P. de Souza, and M. Grosjean

2006 Emergencia de comunidades pastoralistas formativas en el sureste de la Puna de Atacama. Estudios Atacameños 32:93-117.

Núñez, L., I. Cartajena, P. de Souza, C. Carrasco, and M. Grosjean

2006 Informe final Proyecto FONDECYT-1020360.

Núñez, L., and J. Varela

1967 Sobre los recursos de agua y el poblamiento prehispánico de la costa del Norte Grande de Chile. Estudios Arqueológicos 3-4:7-41.

Núñez, L., V. Zlatar, and P. Núñez

1974 Caleta Huelén-42: una aldea temprana en el Norte de Chile (Nota preliminar). Revista Hombre y Cultura, Tomo II (5): 67-103, Centro de Investigaciones Antropológicas, Universidad de Panamá.

Núñez, P.

1992 Sistemas hidráulicos prehispánicos: Patrimonio Cultural. Documento $N^{o} 3$, Universidad de Antofagasta.

Olivera, D.

1998 Cazadores y pastores tempranos de la Puna Argentina. In Past and Present in Andean Prehistory and Early History, edited by S. Ahlgren, A. Muñoz, S. Jodin, and P. Stenberg, pp. 153-180. Etnografiska Museet, Goteborg.

Orellana, M.

1990 Una aldea temprana del Norte de Chile. Creces 3(11):23-28.

Philippi, R.A.

1960 Viage al Desierto de Atacama: Hecho de Orden del Gobierno de Chile en el Verano de 1853-54. Librería de Eduardo Antón, Halle-Sajonia.

Pimentel, G., Ch. Rees, P. de Souza, and P. Ayala

2006 Estrategias de movilidad del periodo Formativo en la depresión intermedia, Desierto de Atacama. Actas XVII Congreso de Arqueología Chilena, pp.1353-1364. Sociedad Chilena de Arqueología, Universidad Austral, Ediciones Kultrún, Valdivia.

Ramírez, J.

1980 Cálculo del Potencial Hídrico de las Nubes Rasantes en el Desierto de Atacama. Universidad del Norte, Antofagasta.

Recabarren, F.

1954 Historia del Proletariado de Tarapacá y Antofagasta (1884-1913). Thesis to obtain the title of Pedagogy in History, Universidad de Chile, Santiago.

Romero, H.I.

2002 The Andes of Chile: Clash between economic and sustainable development. IHDP Update, Newsletter of the Internacional Human Dimensions Programme on Global Environmental Change 1, Artículo 3.

Salazar, D., C. Jiménez, and P. Corrales

2001 Minería y Metalurgia: del cosmos a la tierra, de la tierra al inka. In Tras la Huella del Inka en Chile. Museo Chileno de Arte Precolombino, pp. 60-73, Santiago.

Sandweiss, D.H., McInnis, R.L. Burger, A. Cano, B. Ojeda, R. Paredes, M. del C. Sandweiss, and M.D. Glascock 
1998 Quebrada Jaguar. Early South American Maritime Adaptations. Science 281:1830-1832.

Sanhueza, C.

1991 Orígenes y Desarrollo de la América Indígena Colonial en Atacama. Siglos XVI-XVIII. Thesis presented for the Licenciatura in History. Instituto de Historia, Pontificia Universidad Católica de Chile, Santiago.

2005 Espacio y tiempo en los límites del mundo. Los incas en el despoblado de Atacama. Boletín del Museo Chileno de Arte Precolombino 10(2):51-77.

Schiappacasse, V., V. Castro, and H. Niemeyer 1989 Los desarrollos regionales en el Norte Grande (1000-1400 DC). In Culturas de Chile. Prehistoria, desde sus Orígenes hasta los Albores de la Conquista, edited by J. Hidalgo, V. Schiappacasse, H. Niemeyer, C. Aldunate, and I. Solimano, pp. 181-120. Editorial Andrés Bello, Santiago.

Sinclaire, C.

2004 Prehistoria del Periodo Formativo en la cuenca del Río Salado (Región del Loa Superior): Un estado de la cuestión. Chungara Revista de Antropología Chilena Núm. Especial, Tomo II, pp. 619-639.

Sutulov, A.

1978 Chilean Mining. Mining, and Metallurgical Research Center, Santiago.
Tarragó, M.

1989 Contribución al Conocimiento Arqueológico de las Poblaciones de los Oasis de San Pedro de Atacama en Relación con los Otros Pueblos Puneños, en Especial, el Sector Septentrional del Valle Calchaquíe, Doctoral Dissertation, Universidad Nacional de Rosario, Rosario, Argentina.

Téllez, L.R.

1989 Atacama en el Siglo XVI: La Conquista Hispana en la Periferia de los Andes Meridionales. Cuadernos de Historia 9:45-69. Facultad de Filosofía y Humanidades. Universidad de Chile, Santiago.

\section{UNCED}

1987 Our Common Future. World Commission on Environment and Development.

Vilches, F., Ch. Rees, and C. Silva

2008 Arqueología de asentamientos salitreros en la región de Antofagasta (1880-1930): síntesis y perspectivas. Chungara Revista de Antropología Chilena 40:19-30.

Zolezzi, M.

1993 Historia de los puertos guaneros del litoral de Tarapacá (Hasta 1879). Cuaderno de Investigación Social 34. Centro de Investigación de la Realidad del Norte, Iquique.

\section{Notes}

1 Editor's note: This article was selected from papers presented at the Second Southern Hemisphere Desert Conference held in Arica, Chile, in October 2005.
2 People of Spanish ancestry born in the Atacama and the Loa areas. 
